\title{
1 River flow as a determinant of salmonid distribution and abundance: a review
}

2 M. Warren ${ }^{\mathrm{a}, \mathrm{b}}$, M. J. Dunbar ${ }^{\mathrm{c}}$, C. Smith ${ }^{\mathrm{a}, *}$

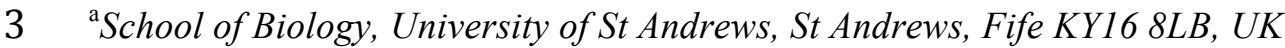

$4 \quad{ }^{\mathrm{b}}$ Environment Agency, Tewkesbury, UK

$5 \quad{ }^{\mathrm{c}}$ Environment Agency, Reading, UK

6

$7 \quad$ *Author for correspondence: Carl Smith, School of Biology, University of St Andrews, St Andrews, Fife $8 \quad$ KY16 8LB, UK (email: cs101@st-andrews.ac.uk) 
9

River flow regime is believed to have a fundamental effect on riverine biota. It influences key aquatic

11 processes, including levels of dissolved oxygen, sediment transport and deposition, water quality and habitat type and distribution. We review the impact of flow on the abundance and distribution of

13 salmonid fishes in the context of developing approaches to regulating, setting and restoring river flow

14 regimes as a means of conserving and managing populations. Flow can have direct impacts on salmonids,

15 both through peak flow resulting in the washout of juveniles, and stranding of all life stages under low

16 flow conditions. Salmonids can also be adversely affected through indirect effects of flow, from impacts

17 on water temperature, dissolved oxygen condition, sediment deposition, and habitat availability. Early life stages, particularly eggs and larvae, appear particularly susceptible to the adverse impacts of flow, since they have a limited capacity for behavioral responses to altered flow conditions. A constraint to conservation and management efforts for salmonids is in selecting river flow targets at the catchment scale with confidence. Most studies linking flow with salmonid population processes are site specific, and may not be readily transferable to other sites. Despite this uncertainty, the requirement for catchment level flow targets has become critical as pressure on water resources has intensified, at the same time that salmonid populations have declined. Our proposal is that hypothesis-led analyses of broad scale longterm datasets are key to quantifying variability in fish abundance with respect to flow and informing flow modification field experiments. The water industry, conservation organizations, and environmental regulators are charged with collaboratively tackling the question of how to set, manage and restore river flow parameters, within the framework of the emerging science of hydroecology. 


\section{Introduction}

31 River flow regimes influence a number of key aquatic processes, including levels of dissolved oxygen, sediment transport and deposition, water quality (through dilution and flushing), and habitat type and 33 distribution (Poff et al., 1997; Richter et al., 1998; Bunn and Arthington, 2002). These processes 34 influence the distribution and abundance of biota and flow regimes can thereby directly or indirectly determine the spatial and temporal distribution of fish (Jowett et al., 2005; Poff and Zimmerman, 2010). Human perturbation of flow, either by directly extracting water, regulating rivers using weirs and dams, or indirectly through patterns of land use, may affect fish populations and communities (Freeman et al., 2001; Cattanéo, 2005; Park et al., 2006; Benejam et al., 2010). Understanding the relationship between flow and fish abundance and distribution represents a key goal in aquatic ecology and fisheries management, and particularly in attempts to manage, restore and rehabilitate rivers for the benefit of aquatic communities (Richter et al., 2003; Souchon et al., 2008; Poff et al., 2010). Because of their ecological and commercial importance, salmonids have been the chief focus of the debate over flow management (Quinn, 2011; Milner et al., 2012).

In recognizing the dominant role of river flow on salmonids an additional consideration is the life-stages affected (Nislow and Armstrong, 2012). The direct and indirect effects of river flow will affect different salmonid life-stages in distinct and sometimes contrasting ways (Johnson et al., 1995; Malcolm et al., 2012; Milner et al., 1998; Nislow and Armstrong, 2012). The impacts of flow that act strongly on developing eggs (Steen and Quinn, 1999) may differ from those impinging on, for example, juveniles (Elliott et al., 1997) or migrating adults (Solomon and Sambrook, 2004). Impacts on different life-stages will depend on the timing and duration of low or high flow events (Bischoff and Wolter, 2001). High flows may have a profound effect on early life stages, whereas periods of low flow may interrupt the migration of adults. The flow requirements of salmonids have been reviewed (Quinn, 2011; Nislow and Armstrong, 2012).

56 The aim of this review is to summarize key scientific studies that demonstrate how river flow can 57 influence the abundance of salmonid fishes, though where relevant, case studies using non-salmonid taxa are also included. A secondary goal is to identify which aspects of flow play the most significant role in 
shaping salmonid populations, and thereby, how this information might be used in river management, and rehabilitation and restoration of rivers for salmonids. The review focuses on salmonids because the bulk of studies that have addressed this question have concentrated on this family of fishes, a reflection of their economic and perceived ecological importance. Many salmonids are also of considerable conservation interest (Allendorf and Waples, 1996). Migratory salmonids occupy entire river catchments, from headwaters to estuaries, with each life stage having some dependency on the different habitat types potentially makes them particularly sensitive to river flow regime alteration. Salmonids have, consequently, been considered good ecological indicators of the impact of flow regime on ecosystems over a broad range of environmental scales (Milner et al., 2012).

Another feature of salmonid biology that makes them a valuable model in understanding the ecological impact of flow is the plasticity of their life-history traits in response to environmental variability (Klemetsen et al., 2003; Rieman and Dunham, 2000). Thus salmonids display wide intra- and interspecific variability in responses to flow variability, with the capacity to adapt to high-gradient upland streams and lowland rivers and estuaries (Beechie et al., 2006; Moore et al., 2012). While this feature of salmonid biology can serve to identify how flow regimes select for specific life-history traits, these adaptive responses also make it difficult to derive generic models of the impacts of flow, with contrasting results generated in different locations (Milner et al., 2012).

\section{Describing river flow}

Hydrologists typically use the term 'flow' to describe the volume of water that is discharged past a single point on a river. The flow regime of a river comprises flow magnitude, frequency, duration, timing and rate of change (Poff et al., 1997). Various numerical variables are used to describe mean, median, peak and low flow rates so that each of these components of water flow can be estimated (Poff et al., 1997; Shaw, 1988). Originally these descriptors were intended for river engineering or water resources management, driven by human population needs, such as flood alleviation or public water supply (Newson, 1994). Regulatory changes over time have shifted the emphasis of river and water resources management towards an ecological basis in order to meet the requirements of legislation, such as the EU Habitats Directive (European Commission, 1992) and the EU Water Framework Directive (European 
of flow required in a watercourse to maintain a healthy ecological state (Arthington et al., 2003; Gibbins et al., 2001; Acreman et al., 2008). The introduction of this term is problematic since quantifying 'environmental flow' is difficult for complex ecological systems, though it at least encapsulates an important concept. Despite these difficulties environmental flows are widely used to set abstraction limits and reservoir releases in river management and are typically defined in terms of departure from some baseline state, such as the 'natural' flow, itself a subjective concept since natural flows will naturally change in response to seasonal and climatic variation (for a full discussion see Poff et al., 1997). If the science and application of environmental flows is to develop, a better quantitative understanding of flow variability and biological response is required (Poff et al., 1997). For this review our goal is to evaluate the evidence for flow induced responses in salmonids, and identify the key aspects of those responses that appear relevant to the setting of environmental flows for salmonid management and as targets for restoration measures. For a recent review of terminology see Milner et al. (2011).

interactions can be placed in context when considering biological responses. This conceptual background is important to those with a biological or ecological background in order to gain some insight into the hydrological disciplines that tend to dominate river and water resources management. Transference can then be made to the rehabilitation of river ecology and restoration of natural features in engineered or degraded rivers. For brevity we employ the term 'restoration' to denote both river rehabilitation and restoration measures.

\section{Determinants of river flow}

109 The natural flow regimes of rivers can vary markedly depending on the sources and components of water runoff. Freeze (1972) partitioned the total runoff from a natural catchment into four component parts:

111 channel precipitation, overland flow, interflow (subsurface flow), and groundwater flow (Freeze, 1972;

112 Ward, 1974). Channel precipitation is that which falls directly onto the river water surface and represents 113 the smallest component, since river surface area will make up only a small percentage of total catchment 114 area. Overland flow is runoff that fails to infiltrate the substrate surface and is determined by the degree 115 of soil saturation. Interflow occurs when water infiltrates the soil and moves laterally through the upper 116 soil horizons to reach river channels. Precipitation that percolates through soils to the underlying water- 
117 bearing strata contributes to the groundwater flow component. Groundwater flow tends to lag behind 118 rainfall events and is important in sustaining river flow during periods of little or no rain. The relative 119 contribution of each of these components will determine the flow regime of a river. When these 120 components are considered alongside other catchment characteristics, such as catchment size, rainfall 121 pattern (spatial and temporal), geology, soil type and topography, an extensive range of river flow 122 regimes will result (Ward, 1974; Newson, 1994; Poff et al., 1997). For example, upland rivers in northern 123 Europe have a high runoff per unit area due to high rainfall and low evapotranspiration, combined with an 124 impermeable geology, steep gradients and thin soils (Burt, 1992; Gilvear et al., 2002). They generally 125 show marked flow peaks and troughs in response to periods of high and low rainfall due to short lag times 126 between rainfall events and changes in river flow (Shaw, 1988). In contrast, lowland alluvial rivers will 127 be influenced more by groundwater. As such, these show relatively more consistent and stable patterns of 128 flow due to a damped response to rainfall and sustained flows in dry periods (Shaw, 1988). A further 129 contrast is found in regions, such as North America, that experience significant precipitation in the form 130 of snow, where river flow can be dominated by patterns of snowmelt. An assumption is that these varying 131 patterns of flow will select for contrasting salmonid life histories, an assumption that appears to be 132 justified (e.g. Elliott, 1995; Beechie et al., 2006). Approaches to understanding river flow regime need to reflect the regional patterns. In the UK, 134 the Institute of Hydrology developed the Base Flow Index (BFI) as a standard approach to apportioning 135 the total river outflow to baseflow (Newson, 1994). The highest BFI scores relate to chalk and other 136 porous limestone catchments, whilst the lowest corresponds to clay-dominated catchments (Table 1). This 137 index provides hydrologists and water resource managers with a comparative guide to identify catchment 138 types that are likely to be prone to low-flow conditions. In the USA, Reidy Liermann et al. (2012) 139 developed a system of classification of rivers with relevance for the Pacific Northwest. Using a Bayesian 140 mixture model they identified seven major classes of flow, a critical first step for setting flow 141 requirements in the region. At a broader scale, Poff (1996) used the hydrological characteristics of 142 relatively undisturbed rivers across continental USA to derive a river classification scheme that reflected 143 patterns of flow variability among rivers. Attempts at a comparable hydromorphological assessment of 144 European rivers have been less comprehensive (e.g. Raven et al., 2002; Downs and Gregory, 2014), though the EU Water Framework Directive now requires a status assessment of all water bodies. 
147 Geomorphology

148 River flow patterns are dependent on the nature of the catchment through which they flow, which in turn

149 is dictated by the underlying geology and topography and ultimately rainfall, the primary determinant of

150 flow patterns (Helliwell et al., 2007). However, despite having similar controls, in terms of hydrology and

151 geomorphology, river flow patterns may still diverge (Schumm, 1985). In addition to pattern diversity,

152 Schumm (1985) noted that rivers also exhibit variation in their stability and resistance to erosion

153 stemming from differences in bank and bed material and hydrological regimes. Nevertheless, the same

154 controls operate at all scales from catchment and whole river at the broadest scale, to river reach at the

155 medium scale, through to small scale processes such as in-channel features and sediment structure

156 (Schumm, 1985; Newson and Newson, 2000). Geomorphological processes define both channel form and

157 the controls on channel form, which ultimately determine channel change (Environment Agency, 1998).

158 The interaction of flow with geomorphology, lithology and valley form are important elements in

159 determining the physical habitat experienced by the biota living within a river (Poff et al., 1997; Newson

160 and Newson, 2000), in particular determining bed scour depth, water velocity and depth, and inter-gravel

161 flow for spawning salmonids and their eggs (Boughton et al., 2009).

162

\section{Natural constraints on river flow}

164 The four main runoff components to river flow (channel precipitation, overland flow, interflow and 165 groundwater flow) are controlled through variations in climatic and catchment factors and their 166 interaction (Ward, 1974; Shaw, 1988; Briggs et al., 1997). These controls are generic in that they 167 influence both high and low river flow through their differing temporal and spatial variation and the 168 nature of the interactions (Figure 1). Low river flows are natural phenomena that are ultimately dependent 169 on a lack of rainfall and limited groundwater inputs. The main processes that sustain river flows in dry 170 weather are storage and discharge from within the catchment consisting of groundwater and subsurface 171 flow, storage in wetlands, lakes or snowmelt (Smakhtin, 2001). Patterns of low flows are determined by 172 temporal variation in the magnitude of low flows, its variability, flow depletion and duration, along with 173 spatial variations due to the regional distribution of rainfall, channel morphology, drainage network and 174 catchment altitude and topography (Shaw, 1988; Briggs et al., 1997; Smakthin, 2001). In general terms, 
175 rivers in catchments with permeable geologies have a greater capacity to sustain river flows than rivers in 176 impermeable catchments.

177 The processes that determine low flow conditions are similar to those that determine flood flow conditions (Figure 1). Again, variation in meteorological and terrestrial components will influence 179 flooding seasonality, frequency, duration and intensity (Ward, 1974; Briggs et al., 1997). Flooding tends 180 to have a seasonal pattern, for example, in northern Britain the majority of flood events $(>78 \%)$ occur in 181 the winter period between October to March, though they have been recorded at all times of year (Black and Werrity, 1997). Although flooding can be seasonal, flood conditions can also occur unpredictably and develop more quickly than low flow conditions, so can be seen as exerting greater influence on riverine communities (Junk et al., 1989; Poff et al., 1997).

\section{Anthropogenic effects on river flow}

187 Globally there are few riverine systems whose flow regime is unaffected by human activities (Ward, 188 1974; Petts, 1984; Sala et al., 2000). A range of human activities is capable of affecting rivers both 189 through direct alteration of river channel habitats or through changes to hydrological and 190 geomorphological processes, which ultimately alter river flow regimes (Poff and Allen, 1995). Dams and 191 other hydraulic structures, agricultural and forestry practices, urbanization and water abstraction have the 192 potential to alter river flow regimes and impact on river biota, including salmonid populations.

\section{Water abstraction and impoundments}

195 Impoundments and abstractions can lead to reduced annual and seasonal flow volumes. Groundwater abstractions can reduce the baseflow of rivers that depend upon this component of runoff to sustain flows during periods of low rainfall (Strevens, 1999; Weber and Perry, 2006). Additionally, headwater streams

198 in high baseflow catchments can dry up, or their sources migrate downstream, thereby reducing habitat 199 availability for fish and other organisms. The reduction of groundwater flow into rivers can also lead to 200 thermal impacts on biota (Caissie, 2006). Salmonids have relatively exacting thermal requirements 201 (Elliott, 1995; Wootton, 1998), with impacts on survival, growth, movement, migration and emergence 202 (Caissie, 2006). In chalk streams in the southern UK, the reduction of relatively cool groundwater is recognized as a potential limiting factor for the survival of salmonids, especially when air and water 
temperatures are elevated (Solomon and Lightfoot, 2008). Similarly, rainbow trout (Oncorhynchus mykiss) in streams in Oregon, USA were dependent on cold water refugia created by upwelling groundwater to persist in warmer stream reaches (Ebersole et al., 2001). especially where large public water supply intakes are in operation. Large water intakes or diversions can disrupt the attractant flow for salmonids during downstream migration, leading to the entrapment of individuals and removal of significant numbers from the spawning population (Solomon, 1992; 211 Aprahamian and Jones, 1997; Turnpenny et al., 1998). Other surface water intakes, for practices such as 212 fish farming and watercress cultivation, tend not to affect the overall water resource budget as they return nearly all the water they use, though they can create river reaches that are depleted of flow and thus 214 present habitat loss and potential barriers to migration for fish (Jones, 1990; Casey and Smith, 1994; 215 Kelly and Karpinski, 1994). Fish farms can also degrade water quality and introduce pathogens to wild 216 fish (Crisp, 1993). Reservoir operations can modify extensively the flow regime of rivers downstream, 217 tending to reduce flow variability and aspects of the flow regime that play a role at specific life history 218 stages (Gustard et al., 1987; Magilligan and Nislow, 2001; Pavlov et al., 2008). For example, flows that 219 would normally transport fine sediment downstream, helping maintain hydromorphological conditions for 220 biota, can be removed resulting in reduced sedimentation of river reaches below the dam. An outcome is 221 coarsening of the substrate, termed 'bed armoring', which limits habitat availability, as well as increasing 222 the risk of 'downcut' or channel erosion (Poff et al., 1997; Pulg et al., 2013; Osmundson et al., 2002). 223 Natural low flow conditions can also be elevated by reservoir compensation flows, which may have been 224 set without any ecological basis (Gustard et al., 1987; Acreman and Dunbar, 2004). Low flows may be 225 needed during the period of emergence of larval salmonids to prevent washout and promote growth 226 (Humphries and Lake, 2000).

\section{Hydropeaking}

229 Flow regulation and management for activities such as hydropower present fish downstream of the point 230 of water release with a strikingly unnatural environment in terms of flow regime. The rapid increase in 231 flows from dam releases (hydropeaking) are non-seasonal, frequent, of high magnitude and have varied duration (Lucas and Baras, 2001). Water released from dams may be at a lower or higher temperature 
233 than the river into which they are released. In some cases released water may be depleted in oxygen, in 234 other cases supersaturated (Lucas and Baras, 2001).

235 The impact of hydropeaking may vary among species and river types. Scruton et al. (2003) 236 detected species-specific behavioral responses in salmonids. Atlantic salmon (Salmo salar) showed two 237 distinct patterns during hydropeaking trials, fish either showed high site fidelity or moved substantial 238 distances in response to water releases. In contrast, brook trout (Salvelinus fontinalis) moved more in 239 relation to releases than to stable flows and also moved more at night in both stable and dynamic flow 240 conditions. Valdez et al. (2001) investigated the effects of dam releases on the Colorado River and found 241 little effect on the distribution, abundance or movement of native fish, proposing that the magnitude and 242 duration of releases were insufficient to displace populations on this river. Hydropeaking has also been 243 associated with strandings, with sudden reductions in flow leaving fish isolated in pools or on exposed 244 substrate (Saltveit et al., 2001; Irvine et al., 2009).

\section{Flood risk management}

247 Mitigating flood risk is a major, though not exclusive, source of river engineering works (Smith and 248 Winkley, 1996; Petts, 2009). Flood risk measures typically involve the straightening and resectioning of 249 river channels to increase conveyance, and gravel removal to lower the riverbed and thereby increase 250 channel capacity (Purseglove, 1988). Impediments to flow are also removed. Thus, boulders and woody 251 debris are removed from the river channel, and riparian vegetation is cut back or removed altogether 252 (Brookes et al., 1983; Harmon et al., 1986). Channelization and river clearance generate structurally 253 simple and hydraulically efficient river channels that facilitate the rapid clearance of water from the 254 floodplain (Brookes, 1985; Hodgson and O’Hara, 1994). These measures have the effect of intensifying 255 the impact of high flows (Poff et al., 1997; Petts, 2009). In addition, the loss of structural complexity and 256 refuge habitats through river modification serve to exacerbate the impact of high flows on fish. Loss of 257 connectivity with the floodplain in particular has the effect of impeding access to low flow conditions, 258 which may be critical spawning habitat or for early life stages (Junk et al., 1989; Poff et al., 1997). The 259 overall impact of flood mitigation activities also tends to alter the ecological function of a river, and 260 thereby fish populations (FAO, 1984; Poff et al., 1997; Pretty et al., 2003). 
263 Riparian land use can influence river flow, primarily through modifying rates of runoff and introducing

264 sediment. A study by Allan et al. (1997) demonstrated that while catchment level patterns of land use 265 predicted runoff and sediment input, local scale land use was uncorrelated. Scale effects of land use have 266 prompted a 'riverscape' approach to management, particularly of salmonids, but also of other fish taxa 267 (Fausch et al., 2002). This approach recognizes that different physical processes that control river flow 268 operate at different spatial scales (Figure 2).

\section{Direct effects of flow on fish}

271 River flow, either high or low, may have an impact on fish directly and may be felt differently at different 272 life-stages (Nislow and Armstrong, 2012). Seasonally high flows and flooding are a dynamic but natural 273 aspect of the character of a river's flow regime and play a critical role in determining the ecological 274 integrity and biological productivity of rivers (Junk et al., 1989; Poff et al., 1997). Periods of low river 275 flow are also natural and often strongly seasonal phenomena that create conditions in the river channel 276 strikingly different to those under high flows. The proportion of high velocity and associated high energy 277 areas are dramatically reduced during periods of low flow, and water depth in these areas tends to be 278 shallow; conditions likely to have an effect directly on the movements and activities of fish (Solomon and 279 Sambrook, 2004; Wissmar and Craig, 2004; Tetzlaff et al., 2008).

\section{Biotic adaptations to flow}

282 River biota exhibit adaptations to the natural heterogeneity of river systems and many organisms show adaptive resilience to a wide range of flows for example through morphological adaptations (suckers, claws or other mechanisms for holding fast in high flow), reproductive strategies (releasing eggs at particular flow events) and tactics to escape in space and time (migrating to specific locations during particular flow periods) (Lehtinen and Layzer, 1988; Southwood, 1988; Townsend and Hildrew, 1994; Vogel, 1994). Flood events may also have the effect of limiting the establishment of invasive species that 288 lack adaptations for high flow conditions (Valdez et al., 2001). A negative impact on fish assemblages may occur when human activity modifies the pattern of river flow so that it deviates from its natural range 
291 drought events may be prolonged. In other circumstances, such as downstream of reservoirs, they may be 292 eliminated altogether.

\section{Effects of high flows}

295 Fish production and growth may be linked to the extent of accessible floodplain (Junk et al., 1989), and 296 nutrient inputs to rivers can be facilitated by high flows flushing adjacent floodplains during periods of 297 high water discharge, thereby enhancing fish productivity (Bowes et al., 2005). In some taxa, spawning is 298 directly related to flood cycles, enhancing reproductive success by creating spawning habitat and nursery 299 areas (Wootton and Smith, 2015). However, the type of river channel and its location within a catchment can determine how floods drive productivity and biotic interactions. Low order streams may experience short and unpredictable flood events, with fish and other aquatic organisms having limited adaptations for using the aquatic/terrestrial transitional zone. Conversely more natural channels or higher order streams have a more predictable and longer flood pulse, with aquatic organisms showing adaptive strategies for utilizing the 'aquatic-terrestrial transition zone' (Junk et al., 1989) (Figure 2). Highly modified channels often preclude access to the transition zone. Fish that occupy rivers with prolonged and predictable floods often show adaptations to exploit the presence of seasonal floods and exhibit life history strategies that maximize their reproductive fitness (Langler and Smith, 2001; Zeug and Winemiller, 2008).

308 Nevertheless, the seasonal timing, magnitude, duration and frequency of flood events will have different 309 effects on the key life stages of fishes (eggs, larvae, juveniles and adult) (Wolter and Sukhodolov, 2008; Poff and Zimmerman, 2010; Konečná et al., 2009), and these are considered separately.

Fish in the early life stages (unhatched egg, embryo and larvae) have a limited capacity actively to seek out preferred habitats and so depend upon drift to transport them to an optimum environment that maximizes their rate of growth and development, and survival (Wolter and Sukhodolov, 2008). However, 314 the timing of drift and the magnitude of displacement will have different optima among species (Reichard 315 and Jurajda, 2007; Pavlov et al., 2008). Unusually large and un-seasonal floods may be detrimental to fish 316 populations by transporting early life stages downstream away from optimum habitat (termed 'washout') 317 or outside the river channel altogether (Fausch et al., 2001; Wolter and Sukhodolov, 2008). Conversely, 318 the absence of natural periodic floods may fail to redistribute early life stages leading to elevated densities and competition (Zitek et al., 2004; Reichard and Jurajda, 2007). In some cases flood events may enable 
early stages to reach floodplain refugia, such as ponds, lakes or ditch systems necessary for them to complete development and/or avoid predation (Seddell et al., 1990; Tockner et al., 2000). In other cases flooding may enable young fishes to migrate down river and recruit to the adult population (Halls and Welcomme, 2004).

The early life stages of salmonids appear susceptible to major floods, despite a widespread view that their preferred river types are relatively high flow velocity environments compared with other freshwater fishes (Sukhodolov et al., 2009). During reproduction their eggs are deposited at an optimum depth in river gravels to minimize the risk of wash out, but sufficiently shallow to ensure adequate oxygenation for egg development and permit larval emergence (Crisp, 1989; Crisp and Carling, 1989). However, extreme floods that mobilize the substrate can damage eggs (Jensen and Johnsen, 1999), although such floods are relatively rare events. The impact of more regular spates are largely mitigated by

331 the depth of egg deposition (Crisp, 1989) and composition and stability of spawning sites, termed 'redds' 332 (Beard and Carline, 1991). Nevertheless, a degree of high flow is needed to promote flushing of fine 333 sediment from gravels to maximize oxygen supply to eggs and embryos (O'Connor and Andrew, 1998; 334 Jensen and Johnson, 1999; Levasseur et al., 2006), although if sediment input exceeds the transport and 335 flushing capability of the river then gravel siltation is inevitable (O'Connor and Andrew, 1998). In 336 addition to oxygen stress on eggs, fine sediment has the capability to entomb embryos and prevent emergence (O’Connor and Andrew, 1998; Jensen and Johnson, 1999). The emergence phase is seen as a 338 critical one, with strong density-dependent mortality at this stage, but density independent factors, such as 339 flooding, can also increase mortality substantially (Elliott, 2006). An adaptation to compensate for the 340 negative effect of floods is that emergence is timed to coincide with a low probability of flooding (Fausch 341 et al., 2001; Elliott, 2006; Lobon-Cervia, 2009). Experimental studies have shown that newly emerged salmonids are most sensitive to wash out, though their susceptibility declines over time, corresponding 343 with an increase in body size and swimming ability (Heggenes and Traaen, 1988).

344 Post-larval juveniles and adults possess an enhanced capacity to navigate their way to preferred 345 habitats, and to seek out refuges during peak flows (Wolter and Sukhodolov, 2008). This capacity 346 suggests that the impact of flooding is likely to be felt less strongly at these stages, though the duration 347 and magnitude of flooding will determine the impact, with unseasonal and exceptionally high flood events expected to have greatest impact. Jurajda et al. (2006) detected only minor effects on a cyprinid 
fish assemblage, and no significant change in fish density, in a tributary of the River Danube,

350 immediately before and after exceptional summer floods during which river discharge peaked at $2000 \%$

351 of the long-term mean. Similarly, the displacement of barbel (Barbus barbus) by high summer flows in a

352 UK river was followed by the fish homing back upstream to their former resident areas (Lucas, 2000).

353 Notably, autumn displacement was more frequent and homing less frequent, suggesting a seasonal 354 element to the effects of displacement (Lucas, 2000).

355 However, in some cases severe flood events have the potential drastically to reduce fish 356 populations and increase the risk of local extinction. Sato (2009) measured dramatic declines (c. 98\%) in 357 a population of Japanese whitespotted char (Salvelinus leucomaenis) inhabiting mountain streams 358 following a severe flood, with no sign of recovery two years after the event. In this case, flood flows were 359 so severe that bank-side debris were mobilized, which had the impact of largely eliminating fish at a local 360 scale and significantly changing the structure of the environment. This study highlights how isolated fish 361 populations in lower order upland streams may be at greater risk of extinction from catastrophic flood 362 events because fish are unable to move readily out of the main river channel in the way they often can in 363 unregulated lowland rivers, and goes some way to supporting the flood-pulse concept (Junk et al., 1989).

364 The flood-pulse concept posits that rivers and their floodplains comprise a single ecological and 365 hydrological system with correlated responses to pulses in river discharge. Observations on stream-living 366 marble trout (Salmo marmoratus) populations have revealed reductions of between $31 \%$ and $78 \%$ 367 following severe flood events prior to spawning, but without long-term consequences to the population.

368 The quick recovery of populations was possible because of a high intrinsic rate of population increase for 369 this species, allowing the small number of reproductive individuals that survived a severe flood to 370 successfully re-establish local populations (Vincenzi et al., 2008). Studies suggest that salmonid 371 reproductive strategies show compensatory responses for dealing with extreme flows, at least within 372 certain limits, which buffer effects at the population level.

\section{Effects of low flows}

375 In low flow conditions the overall volume of water in the river is substantially decreased, with a 376 concomitant reduction in average depth and width of the river channel, which in turn will result in a net 
reduction in available habitat. This situation may present fish with the problem of obtaining access to 378 preferred habitats for feeding, and the risk of oxygen stress.

When flow falls to the point that the risk of stranding or isolation become a serious threat fish rely on refugia habitat for survival until flow conditions improve. Refugia include areas of deeper water

381 (Huntingford et al., 1999; Armstrong et al., 2003), which may include disconnected pools (Labbe and 382 Fausch, 2000; Magoulick and Kobza, 2003). Davey and Kelly (2007) found refugia to be critical in 383 enabling brown trout (Salmo trutta) to persist in a river with naturally intermittent flow in its middle 384 reaches. They showed that brown trout (and other species) moved upstream as the stream dried, with sections subject to drying only slowly recolonized. Rates of colonization correlated negatively with increasing distance to refugia and the fish assemblage in sections susceptible to drying were quantitatively and qualitatively different to neighboring reaches. Davey and Kelly's (2007) findings suggest that river systems can exhibit similar ecological processes predicted from island biogeography theory (MacArthur and Wilson, 1967), with habitat colonization rates negatively correlated with distance from the source of colonizers. From an applied viewpoint this finding has implications for the way habitat quality and its connectivity along river corridors should be viewed and managed. for juvenile salmonids. In the western USA, intermittent rivers comprise over $65 \%$ of total river length and are a source of both spawning and nursery habitat. In a study of coho salmon (Oncorhynchus kisutch), Wigington et al. (2006) showed intermittent rivers to be key sites for the production of smolts, with juveniles able to persist in isolated pools between periods when river flow ceased. to respond to the changed conditions, including dispersal (Pires et al., 1999). However, in many cases dispersal may be limited if there is too little water due to channel constriction (Crisp, 1989; Armstrong et al., 2003). Under the most extreme low flow conditions a river may comprise nothing more than a series

401 of isolated pools. However, even if the river continues to flow as a discrete water body, the appearance of 402 barriers such as gravel banks and boulders, that would be otherwise submerged, may impede fish movement.

A consequence of reduced low flows, then, will be elevated fish density, particularly if fish are 
predation, including cannibalism (Smith and Reay, 1991). In addition, a number of population processes are density dependent. Thus, feeding and growth may be limited, while mortality rates would tend to increase. The transmission of pathogens is often strongly contingent on host density, especially if transmission is direct. In species that show territoriality or dominance hierarchies, which is frequently the

410 case in salmonids, injuries and mortalities associated with aggression may also increase. The negative 411 effects of low flow will depend on the extent of flow limitation, and also the period over which low flows 412 occur. Elliott et al. (1997) noted that a juvenile year class of brown trout subjected to successive drought 413 periods had lower growth rates and increased mortality, which was strongly linked to reduced densities of 414 returning females. Summer droughts may not affect survival as much as low rainfall in spring and summer, or in summer and autumn, when low stream flows can be prolonged. The effects of low flow 416 may also interact with other variables, notably temperature. Solomon and Lightfoot (2010) found 417 correlations between poor salmon stock performance and reduced August flows, possibly linked to 418 temperature effects on spawning migration. High water temperatures will exacerbate hypoxic effects 419 resulting from low flow (Milner et al., 2003), while low winter flows may increase the risk of fish kills 420 from freezing (Huusko et al., 2007). Notably Sabaton et al. (2008) demonstrated increases in the 421 abundance of adult and juvenile brown trout when flows were restored to streams. Although increases in 422 flow were not large, weighted usable area; i.e. available physical habitat, increased substantially in some 423 rivers, suggesting that the impacts of low flow, and attempts to restore flow to rivers, are likely to be 424 highly variable among rivers.

425 The negative impacts of low flow on fish may be especially damaging at the population level if 426 they occur during periods of reproduction. Young stages have a limited capacity to avoid stranding, 427 hypoxia or withstand periods of restricted ration (Wootton, 1998). However, the hyporheic zone may be 428 utilized by the eggs and larvae of some species, and may not be unduly affected by low flows (Baxter and 429 Hauer, 2000), but the risk to salmonids from egg desiccation can be considerable (Crisp et al., 1984; 430 Milner et al., 2003). Furthermore, droughts have been identified as a main cause of severe reductions in 431 the number of YoY salmonids with impacts on population size (Bell et al., 2000; Lobon-Cervia, 2009). 432 These studies also demonstrate the resilience of populations where suitable in-channel habitat exists. 
435 While low and high flow rates can have an impact on salmonids, especially if these are of unusual 436 magnitude or are unseasonal, another little understood impact is through increased variability in flow.

437 Evidence from rivers subjected to pulsed water releases associated with hydropower generation (termed 438 'hydropeaking', see above) suggest that highly variable flows have negative effects on salmonids, 439 especially on young stages. For example, Freeman et al. (2001) showed that high flow variability had a 440 negative effect on juvenile fish by undermining habitat persistence. In a study of stream fish assemblages, 441 Poff and Allan (1995) showed that the effect of a high coefficient of variation of flows generated fish 442 communities distinct from those with low flow variation.

443 Even modest changes in flow can alter the behavior of territorial juvenile salmonids quite 444 substantially. Juvenile salmonids usually rest on the substrate facing upstream under low flow conditions 445 at a specific 'station'. From this point they collect food items that drift along the riverbed or in the water 446 column and engage in aggressive behavior with neighboring territory holders (Jonsson and Jonsson, 447 2011). As flow increases they leave the substrate and swim more frequently in the water column. Here 448 they can see and encounter neighbors more frequently, with a result that territory size increases, with a 449 concomitant reduction in fish density (Kalleberg, 1958; Keenleyside, 1962).

In contrast, Heggenes et al. (2007) observed no difference in the home range size of brown trout

451 (S. trutta) between channelized and natural river sections, and no consistent effects of abrupt changes in 452 flow. The direct effects of flow on fish probably depend on local hydrological conditions, with optimal 453 flows likely to be different in different sections of a catchment. Rosenfeld et al. (2007) proposed that 454 habitat suitability for rainbow trout (O. mykiss) based on hydraulic geometry changed longitudinally 455 along a river. Thus, optimal conditions for juvenile stages were predicted for smaller upstream sections, 456 while those for larger fish were found downstream. These predicted patterns matched empirical data. A summary of stage-specific responses to flow variability is presented in Table 1.

\section{Indirect effects of flow on fish}

River morphology

461 River and water resource management tends to focus solely on the direct impacts of flow (Petts, 2009).

462 However, flow is often simply a surrogate for a more complex interaction between channel morphology, water depth and flow that underpins the availability of habitat for river biota (Brooker and Graynoth, 
2008). Changes to river flow regime can result in changes to both habitat quantity and quality at a range of scales. Because fish migrate among different 'meso' and 'micro' scale habitats there is potential for effects of flow at the population level (Pavlov et al., 2008). Consequently, an understanding of the role of river morphology during different salmonid life stages is important if flow effects are to be understood.

468 Experimental addition and removal of boulders in the Little Southwest Miramichi River by Dolinsek et 469 al. (2007) showed that the presence of boulders significantly increased juvenile Atlantic salmon (S. salar) 470 density, though not of non-salmonid species. The presence of coarse woody debris has also been shown 471 to have a positive effect on juvenile salmonids, primarily by diversifying flow conditions and thereby 472 enhancing feeding opportunities and providing refuges from high flow conditions (Harmon et al., 1986; 473 Roni et al., 2008; Hafs et al., 2014).

\section{Temperature}

476 The energy budgets of fish are driven strongly by water temperature (Rankin and Jensen, 1993; Wootton, 477 1998), which is negatively correlated with flow rate (e.g. Webb et al., 2003). Therefore there are potential 478 consequences of reduced or enhanced flow rates for fish bioenergetics, and ultimately on the survival of 479 certain life stages indirectly through their effect on water temperature (Wootton, 1998). Water 480 temperature also plays a major role in controlling the upstream migration of some salmonids (Quinn et 481 al., 2007; Moore et al., 2012).

\section{Sediment}

484 The rate of transport of sediment is a function of flow, with the greatest volumes of material transported during flood events (Walling and Webb, 1992; Kondolf, 1997; Lenzi and Marchi, 2000). Land management activities, particularly agriculture but also forestry, mining, road construction, effluent 487 discharge, and urban sources, can all result in elevated sediment inputs to watersheds (Henley et al., 2000; 488 Walling and Webb, 1992). Sediment inputs are not wholly rainfall dependent, and so can occur when 489 their impact may be most ecologically damaging (Marks and Rutt, 1997), though rainfall will ultimately 490 determine the rate and volume of sediment transport into and along the river channel. Catchment and river type can also influence sediment transport and deposition processes (Lenzi and Marchi, 2000). 
493 through trophic levels (Osmundson et al., 2002). The avoidance of turbid waters has been observed in 494 juvenile coho salmon $O$. kisutch, arctic grayling Thymallus arcticus, and rainbow trout $O$. mykiss 495 (Newcombe and Jensen, 1996). The negative effects of suspended particles have been observed on 496 juvenile and adult stages in fishes through gill damage (Berg and Northcote, 1985), and reduced feeding 497 rates (Waters, 1995; Argent and Flebbe, 1999). Perhaps, the biggest impact on salmonid production, 498 though, is likely to come from sedimentation affecting oxygen supply and uptake by eggs (see below). A 499 meta-analysis of the impact of sediment on egg to juvenile survival in four species of Pacific salmon by 500 Jensen et al. (2009) showed coho salmon to be most vulnerable and chum salmon least susceptible, while 501 Chinook salmon and migratory rainbow trout showed intermediate sensitivity.

While the transport of large amounts of sediment resulting in fine sediment intrusion is associated 503 with moderate to high flows (Wood and Armitage, 1997), low winter flows at times of low rainfall and 504 icy conditions, can also result in the infiltration of sediment into spawning redds (Levasseur et al., 2006).

505 A consequence is that natural sediment inputs that occur during high flow events can result in less severe ecological effects than at times of low flow (Marks and Rutt, 1997). Hence although periods of high rainfall increase the input of sediment to a river, the effects can be partly be mitigated by dilution and mobilization of sediment under high flow conditions while, counterintuitively, low flow conditions can result in siltation of the river channel (Wood and Armitage, 1997).

Dams have the effect of removing all but the finest suspended sediment, resulting in sediment-

511 depleted water. A common outcome is increased coarsening or 'armoring' of the riverbed, which can limit 512 habitat availability for aquatic invertebrates on which juvenile salmonids feed. Loss of coarse sediment 513 also creates a riverbed that may be unsuitable for spawning by adults (Poff et al., 1997).

516 Well-oxygenated water is important for all salmonid life stages (Armstrong et al., 2003; Hendry et al., 517 2003). Oxygen availability is especially important during egg development, since at this life stage the fish 518 are unable to show a behavioral response to low levels of dissolved oxygen. Fine sediments have multiple 519 impacts on the supply of oxygenated water to developing salmonid eggs and alevins (Crisp, 1996; Grieg et al, 2005a). Fine sediments can limit interstitial flow velocities, while organic sediment has the effect of 
521 depleting dissolved oxygen levels (O’Connor and Andrew, 1998; Acornley and Sear, 1999; Grieg et al, 522 2005a). Clay particles create low permeability seals on the surface of salmonid eggs, greatly reducing 523 rates of oxygen consumption (Grieg et al, 2005b).

524 Dissolved oxygen concentration and water flow are often correlated, and the relationship between 525 flow and dissolved oxygen availability often confounds links between flow and other variables (Downes, 526 2010). Low summer flows and elevated temperatures in rivers are associated with reductions in dissolved 527 oxygen concentration. These effects occur through reduced oxygen solubility and an elevation in oxygen 528 consuming processes at higher temperatures. At low flow rates water turbulence is also reduced, which 529 limits re-aeration of oxygen-depleted water. Fish growth and activity increase with a rise in temperature 530 to an optimum, at which point they become increasingly constrained by oxygen availability (Jonsson and 531 Jonsson, 2009). Reduced oxygen levels can also lead to greater susceptibility to disease (Johnson et al., 532 2009), and to a reduction in migration into freshwater by salmonids (Solomon and Sambrook, 2004).

\section{Pollutants, nutrients, $B O D$}

535 Water quality can be a limiting variable for salmonid population productivity. Efforts to rehabilitate rivers 536 for salmonids and other fishes may not be fully realized if water quality is limiting (Ormerod, 2003). 537 River flow exerts an effect on water chemistry through a dilution effect (Webb and Walling, 1992). High 538 flow rates may also mitigate the anoxic effects of organic pollutants. Reduced flow conditions tend to 539 exacerbate the impacts of pollutants (Smakhtin, 2001), which can be further aggravated at elevated water 540 temperatures when pollutants tend to have greater toxicity (Alabaster and Lloyd, 1982; Mason, 2002). 541 Episodic pollution events without adequate dilution, during periods of limited flow, have the greatest 542 impact and can lead to ecosystem degradation (McCahon and Pascoe, 1990).

\section{Aquatic and riparian vegetation}

545 Indirect impacts of river flow on salmonids can come through effects on other components of the river

546 community, particularly instream and riparian vegetation. Instream, but particularly riparian tree cover, is 547 important in providing shade and thereby plays a role in water temperature regulation (Eklöv et al., 1999). 548 Vegetation can additionally enhance the production of macroinvertebrates (Robinson at al., 2002; Gowan 549 and Fausch, 2002), an important food supply for salmonids that can determine their local distribution 
550 (Kawaguchi and Nakano, 2001). Coarse woody debris is recognized as an important component of habitat

551 structure. It functions by regulating sediment transport, effects debris and sediment accumulation, and

552 dissipates energy by impeding flow and providing refuges for fish and invertebrates (Van Kirk and

553 Benjamin, 2001).

Productivity and bioenergetics

556 Rate and variance of river flow can influence rate of food delivery to salmonids, primarily in the form of 557 drifting invertebrates that are of either terrestrial or aquatic origin (Kawaguchi and Nakano, 2001). The 558 energetic costs of holding station in a river to feed influences fish energy expenditure, as does water 559 temperature, thus the impact of flow can influence salmonids through the structure and balance of their 560 energy budgets. Field studies with salmonids have shown that those in fast currents attain higher food 561 consumption rates than those in slower currents but experience lower growth rates through greater energy 562 expenditure (Tucker and Rasmussen, 1999).

\section{Managing river flow}

565 Directly or indirectly river flow can influence different aspects of salmonid life cycles, as well as being 566 important to other river biota. Other reviewers have viewed the evidence base as inconsistent, with 567 scientific testing lacking (Milner et al., 2011), and to a degree this is true. Nevertheless, the current 568 review provides sufficient evidence to implicate river flow as an appropriate variable for ecologically569 based river management and restoration, though this approach has rarely been used in practice. 570 Traditionally, river flow management has been the realm of hydrologists and river engineers principally 571 concerned with reducing flood risk while improving, or at least maintaining, water supply infrastructure 572 (Shaw, 1988; Newson 1994). However there has been growing recognition of the importance of setting 573 environmental flows, with over 250 different procedures now employed in at least 20 countries (Dunbar 574 et al., 2012). How are environmental flows established?

577 The reviews of Acreman and Dunbar (2004) and Dunbar et al. (2012) summarized the different methods 578 for establishing environmental flows into four main categories; look-up tables, desktop analysis, 
functional analysis, and hydraulic-habitat modeling (Table 3). These approaches encompass a wide range of scales and situations (Table 3), and both reviews concluded that these approaches should not be viewed in isolation, but should form part of a framework (and continuum of methods) where the application of a methodology is determined by factors such as cost, time, perceived environmental risk, availability of

583 expertise, and scale of assessment (whole system through to single site or species). There is a tendency in 584 setting environmental flows to select some aspect of the natural flow regime, for example mean flow or 585 low flow, as a reference point (Richter et al., 1997, 1998, 2003; Poff et al., 2010). However, little reference is made to the ecological conditions associated with natural flows, possibly due to the confounding effects of other environmental pressures (Bunn and Arthington, 2002; Dunbar et al., 2012), and because few river systems worldwide are unaffected by human activity in some way (Richter et al., 1997; Lytle and Poff, 2004; Welcomme, 2008), which limits the opportunity for identifying the relationship between natural flow conditions and river ecology. Reference condition models, particularly 591 the River Invertebrate Prediction and Classification System (RIVPACS) for macroinvertebrates, go some 592 way to helping establish a reference community (Wright et al., 1998). However, the adequacy of such models within environmental flow setting is questionable where measured at-site variables (river depth, wetted width and substrate composition) are used for biological prediction, as these variables are likely to naturally vary in response to flow (Harrison et al., 2004). Where alternative variables can be used 596 adequately, this may offer some opportunity to develop similar predictive models for fish communities.

597 In the case of salmonids, and perhaps other river ecosystem components, returning to the natural flow 598 regime may be not always be beneficial, especially in rivers where releases from reservoirs have altered 599 flow significantly and populations appear to be benefitting (Milner et al., 2011). Thus, unnatural flow 600 conditions can be envisaged, such as enhanced summer flows, that might significantly enhance survival 601 and growth at critical periods that might otherwise limit population size or productivity (Nislow and 602 Armstrong, 2012). A further consideration is the impact of a salmonid population that has been 603 'enhanced' through flow management on ecosystem function. Impacts are potentially detrimental, for 604 example through elevated rates of predation, or might be relatively benign. In the case of lowland rivers 605 in the UK, the majority of which have been highly modified (Brookes, 1988), the concept of what 606 'natural' means in the context of river flow regime is equivocal. Elsewhere, natural flow regimes may be 607 less ambiguous (Pettit et al., 2001; Lytle and Poff, 2004; Propst and Gido, 2004). In situations where 
natural flow regime may be difficult to define, flow management might be targeted specifically at generating a temporal pattern of flow to create the conditions that maximize salmonid production. The challenge in this case is to identify what those flow conditions are.

\section{Habitat management and restoration}

613 It is widely acknowledged that a range of pressures affect riverine ecosystems, but there is also a view 614 that given these pressures, it is habitat quality that limits ecosystem function (Ward et al., 2001; Giller, 615 2005). This view has led to efforts aimed at restoring or rehabilitating river habitat, and as a practice has 616 gained in popularity in river and catchment management over several decades (Holmes, 1998; Ormerod, 617 2003; Palmer et al., 2005). The underlying principles employed takes account of the interaction between 618 habitat and river flow by focusing on establishing site or reach scale in-channel features to create 619 hydraulic complexity as guided by geomorphological processes (Kemp et al., 2000; Pretty et al., 2003; 620 Harrison et al., 2004; Newson and Large, 2006; see Roni et al., 2008 for comprehensive review).

A common in-channel approach to targeting salmonid populations is to focus on the availability and quality of spawning gravels to ensure recruitment conditions are optimal. Spawning habitat rehabilitation is a widely used tool in European rivers in (Brown and Pasternack, 2009; Pederson et al., 2009; Vehanen et al., 2010). In North America, while the introduction of gravel in sediment-starved river systems has proven beneficial (Merz et al., 2004, 2005), the practice is not common (Roni et al., 2008).

626 Whilst focusing on ensuring reproductive success makes some sense, efforts in this direction appear to 627 have met with mixed or, in some cases, limited success. Pulg et al. (2013) examined the provision of 628 gravel and its regular cleaning as a mechanism for restoring brown trout populations in regulated rivers. 629 The positive effects appeared to be short-lived, which suggests that the maintenance of an appropriate 630 flow regime to replenish spawning gravels and keep them free of fine sediment is a more sustainable approach. Salmonid spawning habitat is highly dependent upon the delivery of suitable spawning material

632 from upstream to downstream reaches, and the use of hydraulic models may help determine the discharge 633 required to renew the spawning substrate (Hauer et al., 2011). On balance, simply implementing a 634 minimum flow regime alone as part of attempts at management or restoration is unlikely to rehabilitate 635 salmonid spawning habitat, since the geomorphological processes needed to generate the desired physical 636 habitat could be missing (Brown and Pasternack, 2008). In certain situations specific habitat types may be 
more critical than flow regime. Sukhodolov et al. (2009) showed that braided channels in alpine streams

638 provide refugia for larval and juvenile fish during floods. However, many alpine rivers have lost their

639 braided structure, so restoration of this habitat feature in this instance may represent the priority.

Other categories of river rehabilitation can address riparian rehabilitation, floodplain

641 connectivity, road improvement, and nutrient enrichment (reviewed by Roni et al., 2008). Understanding

642 the ecological benefits of rehabilitation works is important to guiding on-going river habitat management,

643 and poor monitoring programs can be a handicap (Holmes, 1998; Hendry et al., 2003; Giller, 2005).

644 Pederson et al. (2009) advocated an evaluation of gravel re-introduction for salmonids in Danish streams

645 that acknowledged differences in habitat quality among reaches within a river system. To understand

646 habitat quality in a quantitative manner requires a comprehensive monitoring design (Jähnig et al., 2009).

647 One approach is the use of a Before/After, Control/Impact (BACI) design, but even this approach is not

648 without limitations. For instance, it is a common feature of natural systems for populations at two sites to

649 diverge or converge through time, even without an effect resulting from activities at the 'impact' site

650 (Underwood, 1991). Vehanen et al. (2010) used the BACI approach three years prior and post restoration

651 with an unmodified control. Streambed complexity increased, but no effects on brown trout stocks in

652 rehabilitated areas were detected. Moreover 2+ and older age classes decreased in abundance. A severe

653 drought after the scheme reduced densities of trout to a low level in all streams, overriding any beneficial

654 local effects of rehabilitation. This finding suggests that large-scale regional factors may overwhelm local

655 management efforts, and although suitable habitat exists, flow stress can severely limit restoration efforts.

656 River restoration is essentially based on a premise that if habitat conditions are suitable, the biota

657 will respond positively, an approach termed the 'Field of Dreams hypothesis'; "if you build it, they will

658 come." (Palmer et al., 1997). Despite its obvious weaknesses, this approach is often advocated on the

659 basis that a lack of knowledge in quantifying biological processes should not be a barrier to action. A

660 more rational approach, what has been termed 'process-based restoration aims' (Beechie et al., 2010), is to

661 employ habitat restoration and rehabilitation measures alongside the activities of ecologists that have both

662 field and quantitative skills to design restoration measures, implement monitoring protocols and, what has

663 hitherto been a significant omission, to devise appropriate statistical analyses to demonstrate ecological

664 benefits. 
667 A wide range of approaches to environmental flow setting exist worldwide, supported in part by research 668 and expert opinion (Acreman et al., 2005; Roni et al., 2008; Dunbar et al., 2012; Milner et al., 2012). In 669 the UK, attempts have been made to set environmental standards to meet the EU WFD by defining water 670 abstraction limits to protect river systems and appropriate flow releases from reservoirs. These were 671 established using a combination of site-specific data, expert opinion and stakeholder groups (Acreman 672 and Ferguson, 2010). Many empirical studies worldwide have been conducted at a site-specific level, 673 which provides useful detailed information but for only one or a few sites, so their transferability to 674 unknown sites, or to a catchment scale is questionable (Petts, 2009; Acreman and Ferguson, 2010). 675 Nevertheless widely applicable and generalized models are emerging. For example, Booker and Acreman 676 (2007) analyzed data from 63 PHABSIM studies and found strong relationships between single measures 677 of channel form and river hydraulics and the availability of habitat for target species. Estimates of 678 physical habitat sensitivity to flow change from single measures were comparable with full PHABSIM 679 predictions, albeit with greater uncertainty, though some ambiguity may be acceptable in a more risk680 based flow setting framework. The modeling approach by Dunbar et al. (2010a,b) has also shown a 681 generic biological response to flow change. A macroinvertebrate community index responded positively 682 to low and high flow and interacted significantly with river channel modification whereby less modified 683 sites had overall higher biotic index scores and appeared to be more resilient to flow reduction. This 684 finding has implications for flow management and restoration by indicating the likely direction of 685 ecological change in response to flow and habitat alteration. The value of this approach is that it can be 686 applied to a range of sites where little or no biological data exist. Notably the models of Dunbar et al. 687 (2010a,b) utilized existing river flow, river habitat and macroinvertebrate data, obtained from a well688 established monitoring network of the Environment Agency. This approach tallies with the view of Petts 689 (2009) who proposed that models that incorporate long-term data sets are needed so that population level 690 responses can be predicted.

A potential impediment to translating research results into flow management and restoration 692 measures may be because appropriate expertise is fragmented across the disciplines of ecology, 693 hydrology, geomorphology and civil engineering (Vaughan et al., 2009). An understanding of each field 694 is needed to fully interpret results in order to make sound management decisions; a minimum requirement 
695 is that the essential ecological and morphological responses are understood in order to select suitable flow 696 management methods (Jowett, 1997), and move to ecologically sustainable water management (Richter et 697 al., 2003). However, this situation is changing with the recognition of the potential role of hydraulic698 habitat modeling (Dunbar et al., 2012).

\section{Long-term datasets and monitoring}

701 For the management of many ecological systems it is necessary to employ a long-term perspective. 702 Despite the general acceptance of this view, the availability of long-term data to support management 703 remains conspicuously limited (Bayley and Li, 1992; Jackson and Füreder, 2006). Many studies tend to be undertaken over a 3-year time-scale, chiefly a consequence of the typical length of research funding

705 awards, but long time-series data are considerably more valuable and have substantially helped advance 706 our understanding of the temporal patterns of abundance (Elliott, 1995; Magurran, 2011). Furthermore, 707 analyses of long-term datasets are more likely to identify spatial and temporal trends that are key to 708 decision-making, something that short-term studies often fail to detect (Poff et al., 2010; Reidy Liermann 709 et al., 2012). Protocols for detecting ecosystem perturbations require comprehensive time-series data for a 710 suite of key indicators (Richter et al., 1996). For example, long-term studies of freshwater 711 macroinvertebrates have improved our understanding of their inter-annual variation and cycles, biotic and 712 abiotic interactions, and the effects of disturbance and recovery (Jackson and Füreder, 2006). It is 713 important to undertake similar studies of long-lived species, such as salmonids, in order to improve our 714 ecological knowledge, develop suitable models (Elliott, 1995), and detect long-term effects of human 715 impacts on salmonid productivity (Ugedal et al., 2008). In this regard the environmental regulation bodies 716 are in a unique position to adopt such an approach, and for salmonids they should be able to make best 717 use of existing information from national monitoring programs (Milner et al., 2011), including measures 718 of water quality ideally integrated with management strategies (see Poole et al., 2004 for discussion).

719 Additionally, long-term hydrological datasets are often available for rivers supporting salmonids, and 720 these can provide a detailed history of hydrological change to be considered alongside salmonid and 721 habitat assessment data. 
724 autocorrelation between variables to be discerned. This limitation can be overcome to a degree when 725 carrying out hypothesis-led data analyses and model validation, whilst accepting that in some instances

726 monitoring improvements will be needed to ensure they are statistically robust (Milner et al., 2011).

727 However, alterations to monitoring schemes are often viewed unfavorably by organizations that perform

728 these functions; they see it as expensive and potentially render all previous data collection redundant. For 729 salmonids, a parallel approach to the analysis of long-term datasets is needed that uses site-specific 730 studies based upon agreed monitoring protocols so that adequate meta-analyses can be performed (Milner 731 et al., 2011).

\section{Conclusions}

734 The direct and indirect effects of river flow will affect different fish life-stages in distinct ways but 735 responses appear to be highly variable and attempts to generalize among salmonid species and 736 hydrological regimes has proven problematic. Where river flow has a significant impact on salmonid 737 distribution and abundance, its effects may be imposed over an extended period or over a series of short, 738 but possibly extreme, episodes. Despite these highly variable effects upon salmonid populations, and 739 other river biota, many environmental organizations around the world base their management decisions 740 using relatively simple river discharge values (Acreman et al., 2008). This approach is unsurprising since 741 many have invested significant resources in establishing river flow measurement networks. Additionally, 742 biological monitoring networks have been established, principally in isolation from flow measurement 743 networks, and mainly as a response to industrial pollution and the need to manage water quality. Research 744 to date has shown biological response to flow, but causal links are opaque, possibly due to the correlation 745 between river flow and other environmental variables. Furthermore, other factors that relate to river 746 habitat quality and extent cannot be overlooked. Therefore, although there are developments in 747 continuous simulation models which mean that gauged flows are not always required, the adequacy of the 748 current network of flow and biological monitoring, together with data analysis capability represent a 749 potential bottleneck to rational management measures and attempts at river restoration for salmonids, and should be reviewed and amended were possible.

Given the current paucity of long-term datasets tailored to salmonid management and restoration, 
753 macrophytes and invertebrates have demonstrated a range of periodicities in responses to river flow

754 (Dunbar et al., 2010a,b; Acreman and Dunbar, 2011). Furthermore, long-term reductions in flow regime

755 have coincided with reductions in fish populations, though population cycles or trends unrelated to

756 hydrology cannot always be excluded (Bayley and Li, 1992; Acreman and Dunbar, 2011). Empirical

757 models, exploiting long-term data to reveal generalized relationships between flow, habitat quality and

758 macroinvertebrate communities, have been developed which could potentially be applied to assessing

759 river discharge regimes and informing future water resources management (Dunbar et al., 2010a,b), at

760 least in UK rivers for which these data are available. For salmonids there is a pressing need to develop

761 generalized models of flow and habitat requirements that are transferable between river systems (Milner

762 et al., 2011) and, possibly, species. In order to improve our understanding, and further develop such

763 models, there is a requirement for empirical testing; possibly via adaptive management studies with a

764 common design to ensure subsequent meta-analyses are statistically robust.

765 


\section{References}

766

767

768

769

770

771

772

773

774

775

776

777

778

779

780

781

782

783

784

785

786

787

788

789

790

791

792

793

794

795

796

Acornley, R.M., Sear, D.A. 1999. Sediment transport and siltation of brown trout spawning gravels in chalk streams. Hydrol. Process. 13, 447-458.

Acreman, M.C., Dunbar, M.J. 2004. Defining environmental river flow requirements-a review. Hydrol. Earth Sys. Sci. 8, 861-876.

Acreman, M.C., Dunbar, M.J., 2011. Ecologically acceptable flows in chalk rivers. Final report November 2011. Environment Agency, UK.

Acreman, M.C., Dunbar, M.J., Hannaford, J., Black, A.R., Rowan, J.S., Bragg, O.M., 2005. Development of environmental standards (water resources). Stage 1: identification of hydro-morphological parameters to which the aquatic ecosystem is sensitive. Project WFD48, SNIFFER.

Acreman, M., Dunbar, M., Hannaford, J., Mountford, O., Wood, P., Holmes, N., Cowx, I., Noble, N., Extence, C., Aldrick, J., King, J., Black, A., Crookall, D., 2008. Developing environmental standards for abstractions from UK rivers to implement the EU Water Framework Directive. Hydrol. Sci. 56, 1105-1119.

Acreman, M.C., Ferguson, A.J.D. 2010. Environmental flows and the European Water Framework Directive. Freshwat. Biol. 55, 32-48.

Alabaster, J.S., Lloyd, R., 1982. Water Quality Criteria for Freshwater Fish. Butterworth: London.

Allan, J.D., Erickson, D.L., Fay, J., 1997. The influence of catchment land use on stream integrity across multiple spatial scales. Freshwat. Biol. 37, 149-161.

Allendorf, F.W., Waples, R.S. 1996. Conservation and genetics of salmonid fishes. In: Conservation genetics: case histories from nature (J.C. Avise and J.L. Hamrick, eds), pp. 238-280. Chapman and Hall, New York.

Aprahamian, M.W., Jones, G.O., 1997. The seaward movement of Atlantic salmon smolts in the Usk estuary, Wales, as inferred from power station catches. J. Fish. Biol. 50, 442-444.

Argent, D.A., Flebbe, P.A., 1999. Fine sediment effects on brook trout eggs in laboratory streams. Fish. Res. 39, 253-262.

Armstrong, J.D., Kemp, P.S., Kennedy, G.J.A., Ladle, M., Milner, N.J., 2003. Habitat requirements of Atlantic salmon and brown trout in rivers and streams. Fish. Res. 62, 143-170.

Arthington, A.H., Rall, J.L., Kennard, M.J., Pusey, B.J., 2003. Environmental flow requirements of fish in Lesotho Rivers using the DRIFT methodology. River Res. Appl. 19, 641-666.

Baxter, C.V., Hauer, F.R., 2000. Geomorphology, hyporheic exchange, and selection of spawning habitat by bull trout (Salvelinus confluentus). Can. J. Fish. Aquat. Sci. 57, 1470-1481. 
Bayley, P.B., Li, H.W., 1992. Riverine fishes, in: Calow, P., Petts, G.E., (Eds.), The Rivers Handbook: Volume 1. Blackwell, Oxford, pp. 251-281.

Beard, T.D., Carline, R.F., 1991. Influence of spawning and other stream habitat features on spatial variability of wild brown trout. Trans. Amer. Fish. Soc. 120, 711-722.

Beechie, T., Buhle, E., Ruckelshaus, M., Fullerton, A., Holsinger, L. 2006. Hydrologic regime and the conservation of salmon life history diversity. Biol. Conserv. 130, 560-572.

Beechie, T.J., Sear, D.A., Olden, J.D., Pess, G.R., Buffington, J.M., Moir, H., Roni, P., Pollock, M.M., 2010. Process-based principles for restoring river ecosystems. BioScience 60, 209-222.

Bell, V.A., Elliott, J.M., Moore, R.J., 2000. Modelling the effects of drought on the population of brown trout in Black Brows Beck. Ecol. Model. 127, 141-159.

Benejam, L., Angermeier, P.L., Munné, A. García-Berthou, E., 2010. Assessing effects of water abstraction on fish assemblages in Mediterranean streams. Freshwat. Biol. 55, 628-642.

Berg, L., Northcote, T.G., 1985. Changes in territorial, gill-flaring and feeding behaviour in juvenile Coho salmon (Oncorhynchus kisutch) following short-term pulses of suspended sediment. Can. J. Fish. Aquat. Sci. 42, 1410-1417.

Bischoff, A., Wolter, C., 2001. The flood of the century on the River Oder: effects on the $0+$ fish community and implications for floodplain restoration. Regul. Rivers: Res. Mgmt, 17, 171-190.

Black, A.R., Werrity, A., 1997. Seasonality of flooding: a case study of North Britain. J. Hydrol. 195, 125.

Booker, D.J, Acreman, M.C., 2007. Generalisation of physical habitat-discharge relationships. Hydrol. Earth Syst. Sci., 11, 141-157.

Boughton, D.A., Fish, H., Pope, J., Holt, G., 2009. Spatial patterning of habitat for Oncorhynchus mykiss in a system of intermittent and perennial streams. Ecol. Freshwat. Fish, 18, 92-105.

Bowes, M.J., Leach, D.V., House, W.A., 2005. Seasonal nutrient dynamics in a chalk stream: the River Frome, Dorset, UK. Sci. Total Environ. 336, 225-241.

Briggs, D., Smithson, P., Addison, K., Atkinson, K., 1997. Fundamentals of the Physical Environment, second ed. Routledge, London.

Brookes, A., 1985. Downstream morphological consequences of river channelization in England and Wales. Geogr. J. 151, 57-62.

Brookes, A., Gregory, K.J., Dawson, F.H., 1983. An assessment of river channelization in England and Wales. Sci. Total Environ. 27, 97-111.

828 Booker, D.J., Graynoth, E., 2008. Instream habitat and flow regime requirements in the Lower Selwyn River. Report No. U08/8. NIWA. 
Brookes, A. 1988. Channelized Rivers: Perspectives for Environmental Management. Wiley and Sons, Chichester.

Brown, R.A., Pasternack, G.B., 2008. Engineered channel controls limiting spawning habitat rehabilitation success on regulated gravel-bed rivers. Geomorphology 97, 631-654.

834 Brown, R.A., Pasternack, G.B., 2009. Comparison of methods for analysing salmon habitat rehabilitation designs for regulated rivers. River. Res. Applic. 25, 745-772.

Bunn, S.E., Arthington, A.H., 2002. Basic principles and ecological consequences of altered flow regimes for aquatic biodiversity. Environ. Manag. 30, 492-507.

838 Burt, T.P., 1992. The hydrology of headwater catchments, in: Calow, P., Petts, G.E., (Eds.), The Rivers Handbook: Volume 1. Blackwell, Oxford, pp. 3-28.

840 Caissie, D. 2006. The thermal regime of rivers: a review. Freshwat. Biol. 51, 1389-1406.

841 Casey, H., Smith, S.M. 1994. The effects of watercress growing on chalk headwater streams in Dorset 842 and Hampshire. Environmental Pollution, 85, 217-228.

843 Cattanéo, F., 2005. Does hydrology constrain the structure of fish assemblages in French streams? Local scale analysis. Archiv. Hydrobiol. 164, 345-366.

Crisp, D.T., 1989. Use of artificial eggs in studies of washout depth and drift distance for salmonid eggs. Hydrobiologia 178, 155-163.

Crisp, D.T., 1993. The environmental requirements of salmon and trout in freshwater. Freshwat. Forum 3, 176-202.

Crisp, D.T., 1996. Environmental requirements of common riverine European salmonid fish species in freshwater with particular reference to physical and chemical aspects. Hydrobiologia 323, 201-221.

Crisp, D.T., Carling, P.A., 1989. Observations on siting, dimensions and structure of salmonid redds. J. Fish Biol. 34, 119-134.

Crisp, D.T., Mann, R.H.K., Cubby, P.R., 1984. Effects of impoundment upon fish populations in afferent streams at Cow Green reservoir. J. Appl. Ecol. 21, 739-756.

Davey, A.J.H. and Kelly, D.J., 2007. Fish community responses to drying disturbances in an intermittent stream: a landscape perspective. Freshwat. Biol. 52, 1719-1733.

Dolinsek, I.J., Biron, P.M., Grant, J.W.A., 2007. Assessing the effect of visual isolation on the population density of Atlantic salmon (Salmo salar) using GIS. River. Res. Applic. 23, 763-774.

Downs, P., Gregory, K., 2014. River Channel Management: Towards Sustainable Catchment Hydrosystems. Routledge, Abingdon.

861 Downes, B.J., 2010. Back to the future: little-used tools and principles of scientific inference can help 862 disentangle effects of multiple stressors on freshwater ecosystems. Freshwat. Biol. 55, 60-79. 
Dunbar, M.J., Alfredsen, K., Harby, A., 2012. Hydraulic-habitat modelling for setting environmental river flow needs for salmonids. Fish. Manage. Ecol. 19, 500-517.

Dunbar, M., Pedersen, M., Cadman, D., Extence, C., Waddingham, J., Chadd, R., Larsen, S., 2010a. River discharge and local-scale physical habitat influence macroinvertebrate LIFE scores. Freshwat. Biol. 55, 226-242.

Dunbar, M., Warren, M., Extence, C., Baker, L., Cadman, D., Mould, D., Hall, J., Chadd, R., 2010 b. Interaction between macroinvertebrates, discharge and physical habitat in upland rivers. Aquatic Conserv. Mar. Freshw. Ecosyst. 20, S31-S44.

Ebersole, J.L., Liss, W.J., Frissell, C.A., 2001. Relationship between stream temperature, thermal refugia and rainbow trout Oncorhynchus mykiss abundance in arid-land streams in the northwestern United States. Ecol. Freshwat. Fish. 10, 1-10.

Eklöv, A.G., Greenberg, L.A., Brönmark, C., Larsson, P., Berglund, O., 1999. Influence of water quality, habitat and species richness on brown trout populations. J. Fish Biol. 54, 33-43.

Elliott, J.M., 1995. Quantitative Ecology and the Brown Trout. Oxford University Press, Oxford.

Elliott, J.M., 2006. Periodic habitat loss alters the competitive coexistence between brown trout and bullheads in a small stream over 34 years. J. Anim. Ecol. 75, 54-63.

Elliott, J.M., Hurley, M.A., Elliott, J.A., 1997. Variable effects of droughts on the density of a sea-trout population over 30 years. J. Appl. Ecol. 34, 5, 1229-1238.

\section{1}

Environment Agency, 1998. River Geomorphology: A practical guide, National Centre for Risk Analysis and Options Appraisal, Guidance Note 18.

European Commission, 1992. Council Directive 92/43/EEC on the Conservation of Natural Habitats and of Wild Fauna and Flora. Official Journal L 206, 22/07/1992 P. 0007-0050.

European Commission, 2000. Directive 2000/60/EC of the European Parliament and of the Council Establishing a Framework for Community Action in the Field of Water Policy. Official Journal of the European Communities L327.

888 FAO, 1984. Report of the thirteenth session of the European Inland Fisheries Advisory Commission Aarhus, Denmark, 23-30 May 1984. FAO Fish. Rep. 311.

890 Fausch, K.D., Taniguchi, Y., Nakano, S., Grossman, G.D., Townsend, C.R., 2001. Flood disturbance 891 regimes influence rainbow trout invasion success among five holarctic regions. Ecol. Applic. 11, 1438-1455.

893 Fausch K.D., Torgersen C.E., Baxter C.V., Li H.W., 2002 Landscapes to riverscapes: bridging the gap 894 between research and conservation of stream fishes. Bioscience 52, 483-498. 
Freeman, M.C., Bowen, Z.H., Bovee, K.D., Irwin, E.R., 2001. Flow and habitat effects on juvenile fish abundance in natural and altered flow regimes. Ecol. Appl. 11, 179-190

Freeze, R.A., 1972. Role of subsurface flow in generating surface runoff 2. Upstream source areas. Water Resour. Res. 8, 1272-1283.

Gibbins, C.N., Soulsby, C., Jeffries, M.J., Acornley, R., 2001. Developing ecologically acceptable river flow regimes: a case study of Kielder reservoir and the Kielder water transfer system. Fish. Manag. Ecol. 8, 463-485.

Giller, P.S., 2005. River restoration: seeking ecological standards. J. Appl. Ecol. 42, 201-207.

903

904

905

Gilvear, D.J., Heal, K.V., Stephen, A., 2002. Hydrology and the ecological quality of Scottish river ecosystems. Sci. Total Environ. 294, 131-159.

Gowan, C., Fausch, K.D., 2002. Why do foraging stream salmonids move during summer? Environ. Biol. Fish. 64, 139-153.

Greig, S.M., Sear, D.A., Carling, P.A., 2005a. The impact of fine sediment accumulation on the survival of incubating salmon progeny: implications for sediment management. Sci. Total Environ. 344, 241258.

Greig, S.M., Sear, D.A., Smallman, D., Carling, P.A., 2005b. Impact of clay particles on the cutaneous exchange of oxygen across the chorion of Atlantic salmon eggs. J. Fish Biol. 66, 1681-1691.

Gustard, A., Cole, G., Marshall, D., Bayliss, A., 1987. A study of compensation flows in the UK. Report No. 99. Institute of Hydrology, UK.

Hafs, A.W., Harrison, L.R., Utz, R.M., Dunne, T., 2014. Quantifying the role of woody debris in providing bioenergetically favorable habitat for juvenile salmon. Ecol. Model. 285, 30-38.

Halls, A.S., Welcomme, R.L., 2004. Dynamics of river fish populations in response to hydrological conditions: a simulation study. River Res. Appl. 20, 985-1000.

Harmon, M.E., Franklin, J.F., Swanson, F.J., Sollins, P., Gregory, S.V., Lattin, J.D., Anderson, N.H., Cline, S.P., Aumen, N.G., Sedell, J.R., Lienkaemper, G.W., Cromack Jr., K., Cummins, K. W. (1986). Ecology of coarse woody debris in temperate ecosystems. Adv. Ecol. Res. 15, 133-302.

Harrison, S.S.C., Pretty, J.L., Shepherd, D.J., Hildrew, A.G., Smith, C., Hey, R.D., 2004. Rehabilitation of lowland rivers: the effects of instream structures on invertebrates. J. Appl. Ecol. 41, 1140—54.

Hauer, C., Unfer, G., Tritthart, M., Habersack, H., 2011. Effects of stream channel morphology, transport processes and effective discharge on salmonid spawning habitats. Earth Surf. Proc. Land. 36, 672-685.

Heggenes, J., Omholt, P.K., Kristiansen, J.R., Sageie, J., Økland, F., Dokk, J.G., Beere, M.C., 2007. Movements by wild brown trout in a boreal river: response to habitat and flow contrasts. Fish. Mgmt. Ecol. 14, 333-342. 
Heggenes, J., Traaen, T., 1988. Downstream migrations and critical water velocities in stream channels for fry of four salmonid species. J. Fish Biol. 32, 717-727.

Helliwell, R.C., Coull, M.C., Davie, J.J.L., Evans, C.D., Norris, D., Ferrier, R.C., Jenkins, A. Reynolds, B., 2007. The role of catchment characteristics in determining surface water nitrogen in four upland regions in the UK. Hydrol. Earth Syst. Sci. 11, 356-371.

933 Hendry, K., Cragg-Hine, D., O’Grady, M.O., Sambrook, H., Stephen, A., 2003. Management of habitat for rehabilitation and enhancement of salmonid stocks. Fish. Res. 62, 171-192.

Henley, W.F., Patterson, M.A., Neves, R.J., Lemly, A.D., 2000. Effects of sedimentation and turbidity on lotic food webs; a concise review for natural resource managers. Review. Fish. Sci. 8, 125-139.

Hodgson, B.P., O’Hara, K., 1994. Fisheries management of the Welsh Dee - a regulated river. Pol. Arch. Hydrobiol. 41, 331-345.

Holmes, N.T.H., 1998. A review of river rehabilitation in the UK, 1990-1996. Technical report W175. Environment Agency, UK.

Humphries, P., Lake, P.S., 2000. Fish larvae and the management of regulated rivers. Regul. Rivers: Res. Mgmt. 16, 421-432.

Huntingford, F.A., Aird, D., Joiner, P., Thorpe, K.E., Braithwaite, V.A., Armstrong J.D., 1999. How juvenile Atlantic salmon, Salmo salar L., respond to falling water levels: experiments in an artificial stream. Fish. Manag. Ecol. 6, 357-364.

Huusko, A., Greenberg, L., Stickler, M., Linnansaari, T., Nukänen, M., Vehanen, T., Koljonen, S., Louhi, P., Alfredsen, K., 2007. Life in the ice lane: the winter ecology of stream salmonids. River Res. Appl. 23, 469-491.

Irvine, R.L., Oussoren, T., Baxter, J.S., Schmidt, D.C. 2009. The effects of flow reduction rates on fish stranding in British Columbia, Canada. River Res. Appl. 25, 405-415.

Jackson, J.K., Füreder, L., 2006. Long-term studies of freshwater macroinvertebrates: a review of the frequency, duration and ecological significance. Freshwat. Biol. 51, 591-603.

Jähnig, S.C., Brunzel, S., Gacek, S., Lorenz, A.W., Hering, D., 2009. Effects of re-braiding measures on hydromorphology, floodplain vegetation, ground beetles and benthic invertebrates in mountain rivers. J. Appl. Ecol. 46, 406-416.

Jensen, A.J., Johnson, B.O., 1999.The functional relationship between peak spring floods and survival and growth of juvenile Atlantic salmon (Salmo salar) and brown trout (Salmo trutta). Funct. Ecol. 13, 778-785. survival of Pacific salmon: a meta-analysis of published studies. Rev. Fish. Sci. 17, 348-359. 
Johnson, A.C., Acreman, M.C., Dunbar, M.J., Feist, S.W., Giacomello, A.M., Gozlan, R.E., Hinsley, S.A., Ibbotson, A.T., Jarvie, H.P., Jones, J.I., Longshaw, M., Maberly, S.C., Marsh, T.J., Neal, C., Newman, J.R., Nunn, M.A., Pickup, R.W., Reynard, N.S., Sullivan, C.A., Sumpter, J.P., Williams, R.J., 2009. The British river of the future: how climate change and human activity might affect two contrasting river ecosystems in England. Sci. Total. Environ. 407, 4787-4798.

Johnson, I.W., Elliott, C.R.N., Gustard, A., 1995. Using the IFIM to model salmonid fish habitat in the River Allen, England. Bull. Fr. Péche Piscic. 355-363.

Jones, J.G., 1990. Pollution from fish farms. Water Environ. J. 4, 14-18.

Jonsson, B., Jonsson, N., 2009. A review of the likely effects of climate change on anadromous Atlantic salmon and brown trout, with particular reference to water temperature and flow. J. Fish. Biol. 75, 2381-2447.

Jonsson, B., Jonsson, N., 2011. Ecology of Atlantic Salmon and Brown Trout: Habitat as a Template for Life Histories. Springer, Berlin.

Jowett, I.G., 1997. Instream flow methods: a comparison of approaches. Reg. Rivers: Res. Mgmt. 13, 115-127.

Jowett, I.G., Richardson, J., Bonnett, M., 2005. Relationship between flow regime and fish abundances in a gravel bed river, New Zealand. J. Fish Biol. 66, 1419-1436

Julien, H.P., Bergeron, N.E., 2006. Effect of fine sediment infiltration during the incubation period on Atlantic salmon embryo survival. Hydrobiol. 563, 61-71.

Jurajda, P., Reichard, M., Smith, C., 2006. Immediate impact of an extensive summer flood on the adult fish assemblage of a channelized lowland river. J. Freshwat. Ecol. 21, 493-501.

Junk, W.J., Bayley, P.B., Sparks, R.E., 1989. The flood pulse concept in river-floodplain systems. Can. Special Publ. Fish. Aquat. Sci. 106, 110-127.

Kalleberg, H., 1958. Observations in a stream tank of territoriality and competition in juvenile salmon and trout. Rep. Inst. Freshwat. Res. Drottning. 39, 55-98.

Kawaguchi, Y., Nakano, S., 2001. Contribution of terrestrial invertebrates to the annual resource budget for salmonids in forest and grassland reaches of a headwater stream. Freshwat. Biol. 46, 303-316. Miramichi River, New Brunswick. J. Fish. Res. Board Can., 19, 625-634.

Kelly, L.A., Karpinski, A.W., 1994. Monitoring BOD outputs from land-based fish farms. J. Appl. Ichthyol. 10, 368-372.

992 Kemp, J.L., Harper, D.M., Crosa, G.A., 2000. The habitat-scale ecohydraulics of rivers. Ecol. Engineer. 16, 17-29. 
Klemetsen, A., Amundsen, P. A., Dempson, J. B., Jonsson, B., Jonsson, N., O'Connell, M. F., Mortensen, E., 2003. Atlantic salmon Salmo salar L., brown trout Salmo trutta L. and Arctic charr Salvelinus alpinus (L.): a review of aspects of their life histories. Ecol. Freshwat. Fish 12, 1-59.

Kondolf, G.M., 1997. Hungry water: effects of dams and gravel mining on river channels. Environ. Manage. 21, 533-551.

Konečná, M., Jurajda, P., Reichard, M., 2009. River discharge drives recruitment success of the European bitterling Rhodeus amarus in a regulated river in central Europe. J. Fish Biol. 74, 1642-1650.

Labbe, T.R., Fausch, K.D., 2000. Dynamics of intermittent stream habitat regulate persistence of a threatened fish at multiple scales. Ecol. Appl. 10, 1774-1791.

1003

Langler, G.J., Smith, C., 2001. Effects of habitat enhancement on a juvenile fish assemblage. Regul. River. 17, 677-686.

Lehtinen, S.F., Layzer, J.B., 1988. Reproductobe cycle of the plains minnow in the Cimarron River, Oklahoma. Southwest. Nat. 33, 27-33.

Lenzi, M.A., Marchi, L., 2000. Suspended sediment load during floods in a small stream of the Dolomites (northeastern Italy). Catena 39, 267-282.

Levasseur, M., Bergeron, N.E., Lapointe, M.F., Bérubé, F., 2006. Effects of silt and very fine sand dynamics in Atlantic salmon (Salmo salar) redds on embryo hatching success. Can. J. Fish. Aquat. Sci. 63, 1450-1459.

Lobon-Cervia, J., 2009. Why, when and how do fish populations decline, collapse and recover? The example of brown trout (Salmo trutta) in Rio Chaballos (northwestern Spain). Freshwat. Biol. 54, 1149-1162.

Lucas, M.C., 2000. The influence of environmental factors on movements of lowland-river fish in the Yorkshire Ouse system. Sci. Total Environ. 251, 223-232.

Lucas, M.C., Baras, E., 2001. Migration of Freshwater Fishes. Oxford: Blackwell.

1018 Lytle, D.A., Poff, N.L., 2004. Adaptation to natural flow regimes. Trends. Ecol. Evol. 19, 94-100.

1019 MacArthur, R.H., Wilson, E.O., 1967. The Theory of Island Biogeography. Princeton University Press, 1020 Princeton.

1021 Magilligan, F.J., Nislow, K.H., 2001. Long-term changes in regional hydrologic regime following impoundment in a humid-climate watershed. J. Amer. Water. Resour. Assoc. 37, 1551-1569.

Magoulick, D.D., Kobza, R.M., 2003. The role of refugia for fishes during drought: a review and synthesis. Freshwat. Biol. 48, 1186-1198.

1025 Magurran, A.E., 2011. Measuring biological diversity in time (and space), in: Magurran, A.E., McGill, B.J. (Eds.), Biological Diversity. Oxford University Press, Oxford, pp. 85-94. 
Malcolm, I.A, Gibbins, C.N., Soulsby, C., Tetzlaff, D., Moir, H.J. 2012. The influence of hydrology and hydraulics on salmonids between spawning and emergence: implications for the management of flows in regulated rivers. Fish. Manage. Ecol. 19, 464-474.

Marks, S.D., Rutt, G.P., 1997. Fluvial sediment inputs to upland gravel bed rivers draining forested catchments: potential ecological impacts. Hydrol. Earth. Sys. Sci. 1, 499-508.

Mason, C.F., 2002. Biology of Freshwater Pollution, fourth ed. Prentice Hall, London.

McCahon, C.P., Pascoe, D., 1990. Episodic pollution: causes, toxicological effects and ecological significance. Func. Ecol. 4, 375-383.

Merz, J.E., Chan, O. Leigh, K., 2005. Effects of gravel augmentation on macroinvertebrate assemblages in a regulated California river. River Res. Appl. 21, 61-74.

Merz, J.E., Setka, J.D., Pasternack, G.B., Wheaton, J.M., 2004. Predicting benefits of spawning-habitat rehabilitation to salmonid (Oncorhynchus spp.) fry production in a regulated California river. Can. J. Fish. Aquat. Sci. 61, 1433-1446.

Milner, N.J., Cowx, I.G., Whelan, K.F. 2012. Salmonids and flows: a perspective on the state of the science and its application. Fish. Manage. Ecol. 19, 445-450.

Milner, N.J., Dunbar, M.J., Newson, M.D., Potter, E.C.E, Solomon, D.J, Armstrong, J.A., Mainstone, C.P., Llewelyn, C.I., 2011. Managing river flows for salmonids: evidence-based practice. Proceedings of a workshop, Pitlochry, 9-1 $1^{\text {th }}$ March 2010. Atlantic Salmon Trust.

Milner, N.J., Elliott, J.M., Armstrong, J.D., Gardiner, R., Welton, J.S., Ladle, M., 2003. The natural control of salmon and trout populations in streams. Fish. Res. 62, 111-125.

Milner, N.J., Wyatt, R.J., Broad, K., 1998. HABSCORE - applications and future developments of related habitat models. Aquatic Conserv: Mar. Freshw. Ecosyst. 8, 633-644.

Moore, A., Bendall, B., Barry, J., Waring, C., Crooks, N., Crooks, L. 2012. River temperature and adult anadromous Atlantic salmon, Salmo salar, and brown trout, Salmo trutta. Fish. Manage. Ecol. 19, 518-526.

Newcombe, C., Jensen, J., 1996. Channel suspended sediment and fisheries: a synthesis for quantitative assessment of risk and impact. North Am. J. Fish. Mgmt. 16, 693-727.

Newson, M.D., 1994. Hydrology and the River Environment. Oxford University Press, Oxford.

Newson, M.D., Large, A.R.G., 2006. 'Natural' rivers, 'hydromorphological quality' and river restoration: a challenging new agenda for applied fluvial geomorphology. Earth. Surf. Proc. Land. 31, 1606-1624.

Newson, M.D., Newson, C.L., 2000. Geomorphology, ecology and river channel habitat: mesoscale approaches to basin-scale challenges. Prog. Phys. Geography. 24, 195-217. 
Nislow, K.H., Armstrong, J.D. 2012. Towards a life-history-based management framework for the effects of flow on juvenile salmonids in streams and rivers. Fish. Manage. Ecol. 19, 451-463.

O'Connor, W.C.K., Andrew, T.E., 1998. The effects of siltation on Atlantic salmon, Salmo salar L., embryos in the River Bush. Fish. Manag. Ecol. 5, 393-401.

Ormerod, S.J., 2003. Current issues with fish and fisheries: editor's overview and introduction. J. Appl. Ecol. 40, 204-213.

Osmundson, D.B., Ryel, R.J., Lamarra, V.L., Pitlick, J., 2002. Flow-sediment-biota relations: implications for river regulation effects on native fish abundance. Ecol. Appl. 12, 1719-1739.

Palmer, M.A., Ambrose, R.F., Poff, N.L., 1997. Ecological theory and community restoration ecology. Restoration Ecol. 5, 291-300.

Palmer, M.A., Bernhardt, E.S., Allan, J.D., Lake, P.S., Alexander, G., Brooks, S., Carr, J., Clayton, S., Dahm, C.N., Shah, J.F., Galat, D.L., Loss, S.G., Goodwin, P., Hart, D.D., Hassett, B., Jenkinson, R., Kondolf, G.M., Lave, R., Meyer, J.L., O’Donnell, T.K., Pagano, L., Sudduth, E., 2005. Standards for ecologically successful river restoration. J. Appl. Ecol. 42, 208-217.

Park, Y.S., Grenouillet, G., Esperance, B., Lek, S., 2006. Stream fish assemblages and basin land cover in a river network. Sci. Total Environ. 365,140-153.

Pavlov, D.S., Mikheev, V.N., Lupandin, A.I., Skorobagatov, M.A., 2008. Ecological and behavioural influences on juvenile fish migrations in regulated rivers: a review of experimental and field studies. Hydrobiologia 609, 125-138.

Pederson, M.L., Kristensen, E.A., Kronvang, B., Thodsen, H., 2009. Ecological effects of re-introduction of salmonid spawning gravel in lowland Danish streams. River. Res. Applic. 25, 626-638.

Pettit, N.E., Froend, R.H., Davies, P.M., 2001. Identifying the natural flow regime and the relationship with riparian vegetation for two contrasting western Australian rivers. Regul. River. 17, 201-215.

Petts, G.E., 1984. Impounded Rivers: Perspectives for Ecological Management. Wiley, London.

Petts, G.E., 2009. Instream flow science for sustainable river management. J. Amer. Water. Resource. Assoc. 45, 1071-1086.

Pires, A.M., Cowx, I.G., Coelho, M.M., 1999. Seasonal changes in fish community structure of intermittent streams in the middle reaches of the Guadiana basin, Portugal. J. Fish Biol. 54, 235-249.

Poff, N., 1996. A hydrogeography of unregulated streams in the United States and an examination of scale-dependence in some hydrological descriptors. Freshwat. Biol. 36, 71-79.

Poff, N.L., Allan, J.D., 1995. Functional organization of stream fish assemblages in relation to hydrological variability. Ecology 76, 606-627. 
Poff, N.L., Allan, J.D., Bain, M.B., Karr, J.R., Prestegaard, K.L., Richter, B.D., Sparks, R.E., Stromberg, J.C., 1997. The natural flow regime. Bioscience 47, 769-784.

Poff, N.L., Richter, B.D., Arthington, A.H., Bunn, S.E., Naiman, R.J., Kendy, E., Acreman, M., Apse, C., Bledsoe, B.P., Freeman, M.C., 2010. The ecological limits of hydrologic alteration (ELOHA): a new framework for developing regional environmental flow standards. Freshwat. Biol. 55, 147-170.

Poff, N.L., Zimmerman, J.K.H., 2010. Ecological responses to altered flow regimes: a literature review to inform the science and management of environmental flows. Freshwat. Biol. 55, 194-205.

Poole, G.C., Dunham, J.B., Keenan, D.M., Sauter, S.T., McCullough, D.A., Mebane, C., Lockwood, J.C, Essig, D.A., Hicks, M.P., Sturdevant, D.J., Maternal, E.J., Spalding, S.A., Risley, J., Deppman, M., 2004. The case for regime-based water quality standards. BioScience 54, 155-161.

Pretty, J.L., Harrison, S.S.C., Shepherd, D.J., Smith, C., Hildrew, A.G., Hey, R.D., 2003. River rehabilitation and fish populations: assessing the benefit of instream structures. J. Appl. Ecol. 40, 233 242.

Propst, D.L., Gido, K.B., 2004. Responses of native and nonnative fishes to natural flow regime mimicry in the San Juan River. Trans. Amer. Fish. Soc. 133, 922-931.

Pulg, U., Barlaup, B.T., Sternecker, K., Trepl, L., Unfer, G., 2013. Restoration of spawning habitats of brown trout in a regulated chalk stream. River. Res. Applic. 29, 172-182.

Purseglove, J., 1988. Taming the Flood. Oxford University Press, Oxford.

Quinn, T.P. 2011. The Behavior and Ecology of Pacific Salmon and Trout. UBC Press, Vancouver.

Quinn, T.P., Hodgson, S., Peven, C., 1997. Temperature, flow, and the migration of adult sockeye salmon (Oncorhynchus nerka) in the Columbia River. Can. J. Fish. Aquat. Sci. 54, 1349-1360.

Rankin, J.C., Jensen, F.B., 1993. Fish Ecophysiology. Chapman and Hall, London.

Raven, P.J., Holmes, N.T.H., Charrier, P., Dawson, F.H., Naura, M., Boon, P.J. 2002. Towards a harmonized approach for hydromorphological assessment of rivers in Europe: a qualitative comparison of three survey methods. Aquat. Conserv. 12, 405-424.

Reichard, M., Jurajda, P., 2007. Seasonal dynamics and age structure of drifting cyprinid fishes: an interspecific comparison. Ecol. Freshwat. Fish 16, 482-492.

Reidy Liermann, C.A., Olden, J.D., Beechie, T.J., Kennard, M.J., Skidmore, P.B., Konrad, C.P., Imaki, H., 2012. Hydrogeomorphic classification of Washington State rivers to support emerging environmental flow management strategies. River Res. Appl. 28, 1340-1358.

Richter, B.D., Baumgartner, J.V., Braun, D.P., Powell, J., 1998. A spatial assessment of hydrologic alteration within a river network. Regul. River. 14, 329-340. 
Richter, B.D., Baumgartner, J.V., Powell, J., Braun, D.P., 1996. A method for assessing hydrologic alteration within ecosystems. Conserv. Biol. 10, 1163-1174.

Richter, B.D., Baumgartner, J.V., Wigington, R., Braun, D.P., 1997. How much water does a river need? Freshwat. Biol. 37, 231-249.

Richter, B.D., Mathews, R., Harrison, D.L., Wigington, R., 2003. Ecologically sustainable water management: managing river flows for ecological integrity. Ecol. Applic. 13, 206-224.

Rieman, B.E., Dunham, J.B., 2000. Metapopulations and salmonids: a synthesis of life history patterns and empirical observations. Ecol. Freshwat. Fish 9, 51-64.

Riley, W.D., Maxwell, D.L., Ives, M.J., Bendall, B., 2012. Some observations on the impact of temperature and low flow on the onset of downstream movement of wild Atlantic salmon, Salmo salar, smolts. Aquaculture 362, 216-223.

Robinson, C.T., Tockner, K., Ward, J.V., 2002. The fauna of dynamic riverine landscapes. Freshwat. Biol. 47, 661-677.

Roni, P., Hanson, K., Beechie, T., 2008. Global review of the physical and biological effectiveness of stream habitat rehabilitation techniques. North Amer. J. Fish. Manag. 28, 856-890.

Rosenfeld, J.S., Post, J., Robins, G., Hatfield, T., 2007. Hydraulic geometry as a physical template for the river continuum: application to optimal flows and longitudinal trends in salmonid habitat. Can. J. Fish. Aquat. Sci. 64, 755-767.

Sabaton, C., Souchon, Y., Capra, H., Gouraud, V., Lascaux, J.M., Tissot, L., 2008. Long-term brown trout populations responses to flow manipulation. River Res. Appl. 24, 476-505.

Sala, O.E., Chapin, F.S., Armesto, J.J., 2000. Biodiversity - global biodiversity scenarios for the year 2100. Science $287,1770-1774$.

Saltveit, S.J., Halleraker, J.H., Arnekleiv, J.V., Harby, A. 2001. Field experiments on stranding in juvenile Atlantic salmon (Salmo salar) and brown trout (Salmo trutta) during rapid flow decreases caused by hydropeaking. Regul. River. 17, 609-622.

Sato, T., 2009. Dramatic decline in population abundance of Salvelinus leucomaenis after a severe flood and debris flow in a high gradient stream. J. Fish Biol. 69, 1849-1854.

Schumm, S.A., 1985. Patterns of alluvial rivers. Ann. Rev. Earth Planet Sci. 13, 5-27.

Scruton, D.A., Ollerhead, L.M.N., Clarke, K.D., Pennell, C., Alfredsen, K., Harby, A., Kelley, D., 2003. The behavioural response of juvenile Atlantic salmon and brook trout to experimental hydropeaking on a Newfoundland (Canada) river. River. Res. Applic. 19, 577-587.

Sedell, J., Reeves, G., Hauer, F., Stanford, J., Hawkins, C., 1990. Role of refugia in recovery from disturbances: modern fragmented and disconnected river systems. Environ. Manag. 14, 711-724. 
1156 Shaw, E.M., 1988. Hydrology in Practice, second ed. Chapman and Hall, London.

1157 Smakhtin, V.U., 2001. Low flow hydrology: a review. J. Hydrol. 240, 147-186.

1158 Smith, C. and Reay, P., 1991. Cannibalism in teleost fish. Rev. Fish Biol. Fish. 1, 41-64.

1159 Smith, L.M., Winkley, B.R. 1996. The response of the Lower Mississippi River to river engineering. Eng. $1160 \quad$ Geol. 45, 433-455.

1161 Solomon, D.J., 1992. Diversion and entrapment of fish at water intakes and outfalls. Research and 1162 Development Publication 4, National Rivers Authority, UK.

1163 Solomon, D.J., Lightfoot, G.W., 2008. The Thermal Biology of Brown Trout and Atlantic Salmon. 1164 Environment Agency Science Report, UK.

1165 Solomon D.J., Lightfoot, G.W., 2010. Variation in salmon abundance on the Hampshire Avon 1166 influences of climate throughout the life cycle. Environment Agency, UK.

1167 Solomon, D.J., Sambrook, H.T., 2004. Effects of hot dry summers on the loss of Atlantic salmon, Salmo 1168 salar, from estuaries in South West England. Fish. Manag. Ecol. 11, 353-363.

1169 Souchon, Y., Sabaton, C., Deibel, R., Reiser, D., Kershner, J., Gard, M., Katopodis, K., Leonard, P., Poff, 1170 N.L., Miller, W.J., 2008. Detecting biological responses to flow management: missed opportunities; 1171 future directions. River Res. Appl. 24, 506-518.

1172 Southwood, T.R.E., 1988. Tactics, strategies and templets. Oikos 52, 3-18.

1173 Steen R.P., Quinn, T.P., 1999. Egg burial depth by sockeye salmon: implications for survival of embryos 1174 and natural selection on female body size. Can. J. Zoology. 77, 836-841.

1175 Strevens, A.P. 1999. Impacts of groundwater abstraction on the trout fishery of the River Piddle, Dorset; 1176 and an approach to their alleviation. Hydrol. Process. 13, 487-496.

1177 Sukhodolov, A., Bertoldi, W., Wolter, C., Surian, N., Tubino, M., 2009. Implications of channel processes for juvenile fish habitats in Alpine rivers. Aquat. Sci. 71, 338-349.

1179 Tetzlaff, D., Gibbins, C, Bacon, P.J., Youngson, A.F., Soulsby, C., 2008. Influence of hydrological 1180 regimes on the pre-spawning entry of Atlantic salmon (Salmo salar L.) into an upland river. River 1181 Res. Appl. 24, 528-542.

1182 Tockner, K., Malard, F., Ward, J.V., 2000. An extension of the flood pulse concept. Hydrol. Process. 14, $1183 \quad 2861-2883$.

1184 Townsend, C.R., Hildrew, A.G., 1994. Species traits in relation to a habitat templet for river systems. 1185 Freshwat. Biol. 31, 265-275.

1186 Tucker, S., Rasmussen, J.B., 1999. Using ${ }^{137} \mathrm{Cs}$ to measure and compare bioenergetic budgets of juvenile 1187 Atlantic salmon and brook trout in the field. Can. J. Fish. Aquat. Sci. 56, 875-887. 
Turnpenny, A.W.H., Struthers, G., Hanson, K.P., 1998. A UK Guide to Intake Fish-Screening Regulations, Policy and Best Practice. Contractors report to the Energy Technology Support Unit, Harwell, Project No. ETSU H/00052/00/00.

Ugedal, O., Næsje, T.F., Thorstad, E.B., Forseth, T., Saksgård, L.M., Heggberget, T.G., 2008. Twenty years of hydropower regulation in the River Alta: long-term changes in abundance of juvenile and adult Atlantic salmon. Hydrobiologia 609, 9-23.

Underwood, A.J., 1991. Beyond BACI: experimental designs for detecting human environmental impacts on temporal variations in natural populations. Mar. Freshwat. Res. 42, 569-587.

Valdez, R.A., Hoffnagle, T.L., McIvor, C.C., McKinney, T., Leibfried, W., 2001. Effects of a test flood on fishes of the Colorado River in Grand Canyon, Arizona. Ecol. Appl. 11, 686-700.

Van Kirk, R.W., Benjamin, L., 2001. Status and conservation of salmonids in relation to hydrologic integrity in the Greater Yellowstone National Park. West. N. Amer. Nat. 61, 359-374.

Vaughan, I.P., Diamond, M., Gurnell, A.M., Hall, K.A., Jenkins, A., Milner, N.J., Naylor, L.A., Sear, D.A., Woodward, G., Ormerod, S.J., 2009. Integrating ecology with hydromorphology: a priority for river science and management. Aquat. Cons: Mar. Freshwat. Ecosys. 19, 113-125.

Vehanen, T., Huusko, A., Mäki-Petäys, A., Louhi, P., Mykrä, H., Muotka, T., 2010. Effects of rehabilitation on brown trout in boreal forest streams. Freshwat. Biol. 55, 2200-2214.

Vincenzi, S., Crivelli, A.J., Jesensek, D., Rubin, J.F., Poizat, G., 2008. Potential factors controlling the population viability of newly introduced endangered marble trout populations. Biol. Conserv. 141, 198-210.

Vogel, S., 1994. Life in Moving Fluids. Princeton University Press, Princeton.

1211 Ward, R.C., 1974. Principles of Hydrology. Second ed. McGraw Hill, London.

1212 Ward, J.V., Tockner, K., Uehlinger, U., Malard, F., 2001. Understanding the natural patterns and processes in river corridors as the basis for effective river restoration. Regul. Rivers. Res. Mgmt. 17, 311-323.

Waters, T.F., 1995. Sediment in streams: sources, biological effects and control. Amer. Fish. Soc. Mono. 7. American Fisheries Society.

Webb, B.W., Clack, P.D., Walling, D.E. 2003. Water-air temperature relationships in a Devon river system and the role of flow. Hydrol. Process. 17, 3069-3084.

Webb, B.W., Walling, D.E., 1992. Water quality II. Chemical characteristics, in: Calow, P., Petts, G.E., (Eds.), The Rivers Handbook: Volume 1. Blackwell, Oxford, pp. 73-100. 
1221 Weber, K.A., Perry, R.G. 2006. Groundwater abstraction impacts on spring flow and base flow in the 1222 Hillsborough River Basin, Florida, USA. Hydrogeol. J. 14, 1252-1264.

1223 Welcomme, R., 2008. World prospects for floodplain fisheries. Ecohyd. Hydrobiol. 8, 169-182.

1224 Wigington Jr, P.J., Ebersole, J.L., Colvin, M.E., Leibowitz, S.G., Miller, B., Hansen, B., Compton, J.E., 1225 2006. Coho salmon dependence on intermittent streams. Frontiers Ecol. Environ. 4, 513-518.

1226 Wissmar, R.C., Craig, S.D., 2004. Factors affecting habitat selection by a small spawning charr 1227 population, bull trout, Salvelinus confluentus: implications for recovery of an endangered species. 1228 Fish. Manag. Ecol. 11, 23-31.

1229 Wolter, C., Sukhodolov, A., 2008. Random displacement versus habitat choice of fish larvae in rivers. 1230 River Res. Appl. 24, 661-672.

1231 Woo, H.S., Julien, P.Y., Richardson, E.V., 1986. Washload and fine sediment load. J. Hydraul. Eng. 112, 1232 541-545.

1233 Wood, P.J., Armitage, P.D., 1997. Biological effects of fine sediment in the lotic environment. Environ. 1234 Manage. 21, 203-217.

1235 Wootton, R.J., 1998. Ecology of Teleost Fishes, second ed. Kluwer Academic Publishers, Dordrecht.

1236 Wootton, R.J., Smith, C., 2015. Reproductive Biology of Teleost Fishes. Wiley-Blackwell, Oxford.

1237 Wright, J.F., Furse, M.T., Moss, D., 1998. River classification using invertebrates: RIVPACS applications. Aquat. Cons: Mar. Freshwat. Ecosys. 8, 617-631.

1239 Zeug, S.C., Winemiller, K.O., 2008. Relationships between hydrology, spatial heterogeneity, and fish 1240 recruitment dynamics in a temperate floodplain river. River Res. Appl. 24, 90-102.

1241 Zitek, A., Schmutz, S., Unfer, G., Ploner, A., 2004. Fish drift in a Danube sidearm-system: I. Site-, 1242 inter-and intraspecific patterns. J. Fish Biol. 65, 1319-1338.

1243

\section{Figure captions}

1245 Figure 1. Identical process controls, but contrasting conditions, leading to either flood flow or low flow in 1246 rivers. Modified from Briggs et al. (1997).

1247 Figure 2. Conceptual model of physical and biotic processes operating at different spatial scales that 1248 influence riverine biota within controls imposed by underlying geology/lithology and geomorphology.

1249 Modified from Labbe and Fausch (2000). 


\section{Low Flow Controls}

\begin{tabular}{|c|}
\hline $\begin{array}{l}\text { METEOROLOGICAL CONTROLS } \\
\text { Precipitation: low volume, infrequent, protracted periods of } \\
\text { limited/no precipitation } \\
\text { Atmospheric pressure: High pressure, increased temperature, } \\
\text { wind speed, high evaporative losses }\end{array}$ \\
\hline TERRESTRIAL CONTROLS \\
\hline $\begin{array}{l}\text { Permanent: catchment characteristics, geology, lithology (e.g. } \\
\text { low gradient and/or permeable), landscape and channel } \\
\text { morphology and network (proximity to groundwater table, } \\
\text { bed permeability leading to losses). }\end{array}$ \\
\hline $\begin{array}{l}\text { Transient: high soil moisture deficit, low groundwater levels, } \\
\text { high vegetation cover (interception and evapo-transpiration } \\
\text { losses }\end{array}$ \\
\hline
\end{tabular}

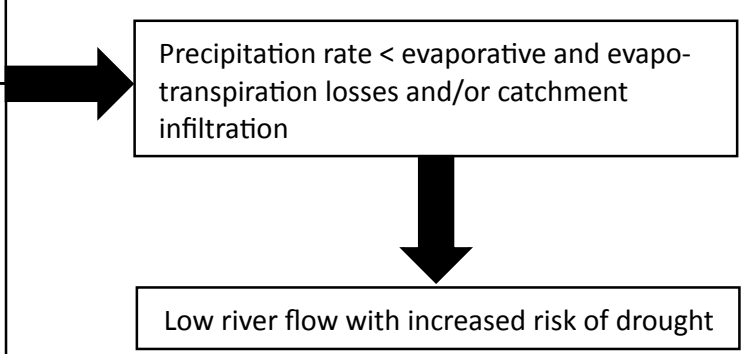

\section{High Flow Controls}

\section{METEOROLOGICAL CONTROLS}

Precipitation: high volume, frequent, extended periods of high precipitation, snow or ice melt

Atmospheric pressure: Low pressure, decreased temperature, storminess, low evaporative losses

\section{TERRESTRIAL CONTROLS}

Permanent: catchment characteristics, geology, lithology (e.g. steep and impermeable), landscape and channel morphology and network (channel length per area of catchment, channel geometry)

Transient: saturated soil, high groundwater levels, reduced vegetation cover (little or no evapo-transpiration losses)

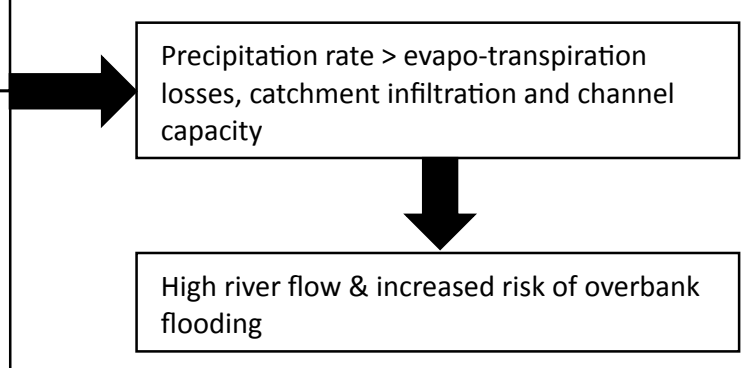




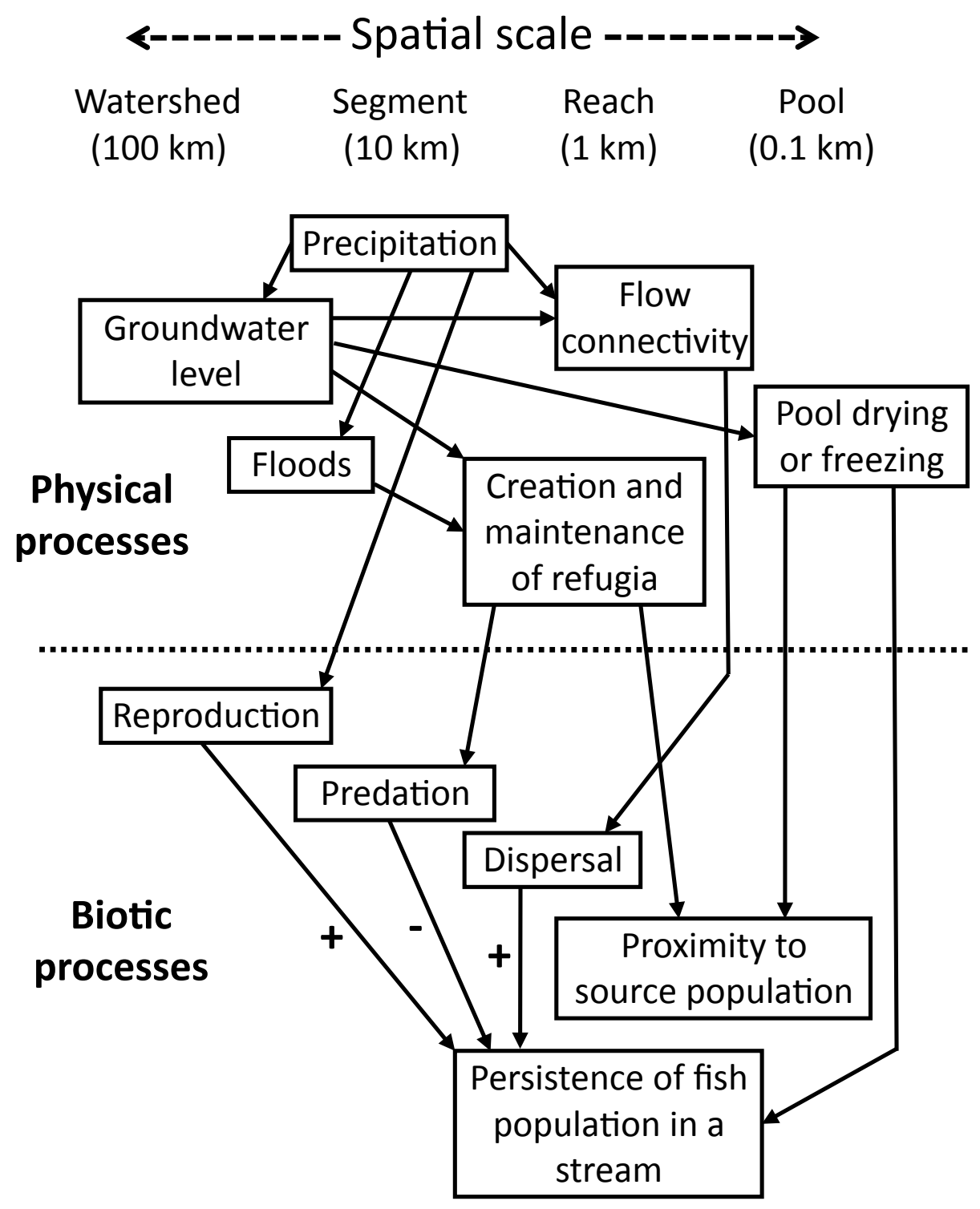

Fig. 2 
Table 1. Life-stage specific impact of contrasting flow characteristics of salmonids among seasons (modified from Nislow and Armstrong, 2012) (NA = not applicable, ? $=$ not known).

\begin{tabular}{|c|c|c|c|c|c|c|}
\hline \multirow[b]{2}{*}{ Season } & \multicolumn{2}{|c|}{ Fry } & \multicolumn{2}{|c|}{ Parr } & \multicolumn{2}{|c|}{ Smolt } \\
\hline & Low flow & High flow & Low flow & High flow & Low flow & High flow \\
\hline Spring & $\begin{array}{l}\text { Lower or } \\
\text { higher } \\
\text { survival }\end{array}$ & $\begin{array}{l}\text { Lower } \\
\text { survival }\end{array}$ & $\begin{array}{l}\text { Reduced } \\
\text { growth }\end{array}$ & $?$ & $\begin{array}{c}\text { Migratory } \\
\text { delay and } \\
\text { lower } \\
\text { survival }\end{array}$ & $\begin{array}{c}\text { Positive or } \\
\text { negative } \\
\text { depending } \\
\text { on timing }\end{array}$ \\
\hline Summer & $\begin{array}{l}\text { Reduced } \\
\text { growth }\end{array}$ & $\begin{array}{l}\text { Reduced } \\
\text { growth }\end{array}$ & $\begin{array}{l}\text { Reduced } \\
\text { growth }\end{array}$ & $\begin{array}{c}\text { Increased } \\
\text { shelter } \\
\text { seeking }\end{array}$ & NA & NA \\
\hline Autumn & NA & NA & $\begin{array}{l}\text { Reduced } \\
\text { growth }\end{array}$ & $?$ & NA & NA \\
\hline Winter & NA & NA & $\begin{array}{l}\text { Positive or } \\
\text { negligible } \\
\text { effect on } \\
\text { growth }\end{array}$ & $\begin{array}{l}\text { Increased } \\
\text { shelter } \\
\text { seeking }\end{array}$ & NA & NA \\
\hline
\end{tabular}


Table 2. Effects of fine sediment on survival of embryonic stage of salmonids.

\begin{tabular}{lll}
\hline Sediment size/description & Effect & Reference \\
\hline $\begin{array}{l}<.063 \mathrm{~mm}-0.5 \mathrm{~mm} \\
\text { Silts/clays }- \text { coarse sand }\end{array}$ & Reduced survival in egg stage & $\begin{array}{l}\text { Julien and Bergeron } \\
(2006)\end{array}$ \\
$<0.125 \mathrm{~mm}$ & $\begin{array}{l}>0.2 \% \text { in redds leads to }<50 \% \\
\text { embryo survival }\end{array}$ & $\begin{array}{l}\text { Levasseur et al. } \\
(2006)\end{array}$ \\
Silt and fine sand & $\begin{array}{l}\text { Thin film on egg surface } \\
\text { reduces oxygen exchange } \\
\text { across membrane }\end{array}$ & Greig et al. (2005) \\
Clay sediment & $\begin{array}{l}>15 \% \text { fine material in redds } \\
\text { deleterious to survival }\end{array}$ & $\begin{array}{l}\text { O'Connor and } \\
\text { Andrew (1998) }\end{array}$ \\
& $\begin{array}{l}\text { Reduced embryo survival } \\
\text { with increased fine sediment. }\end{array}$ & $\begin{array}{l}\text { Argent and Flebbe } \\
\text { Fine sediment }\end{array}$ \\
& $\begin{array}{l}\text { Emergent fry weight also } \\
\text { reduced. }\end{array}$ & \\
$0.43-0.85 \mathrm{~mm}$ & &
\end{tabular}


Table 3. Summary of environmental flow setting categories, example methods, scale of application, and type of situation employed. Adapted from Acreman and Dunbar (2004).

\begin{tabular}{|c|c|c|c|}
\hline Method category & Example [Country] & Scale of application & Situation type \\
\hline \multirow[t]{3}{*}{ Look up table } & $\begin{array}{l}\text { Tennant (Montana) } \\
\text { method [USA] }\end{array}$ & \multirow[t]{3}{*}{ Catchment } & \multirow[t]{3}{*}{ Scoping/planning } \\
\hline & Texas method [USA] & & \\
\hline & Basque method [Spain] & & \\
\hline \multirow[t]{2}{*}{ Desktop analysis } & $\begin{array}{l}\text { Range of Variability } \\
\text { Approach (RVA) [USA } \\
\text { \& others] }\end{array}$ & \multirow[t]{2}{*}{$\begin{array}{l}\text { Catchment/multiple } \\
\text { or single sites }\end{array}$} & \multirow[t]{2}{*}{$\begin{array}{l}\text { Planning/high level } \\
\text { impact assessment }\end{array}$} \\
\hline & $\begin{array}{l}\text { Resource Assessment } \\
\text { and Management } \\
\text { framework (RAM) } \\
\text { [England and Wales] }\end{array}$ & & \\
\hline \multirow[t]{2}{*}{ Functional analysis } & $\begin{array}{l}\text { Building Block Method } \\
\text { (BBM) [South Africa } \\
\text { and others] }\end{array}$ & \multirow[t]{2}{*}{$\begin{array}{l}\text { Multiple or single } \\
\text { sites }\end{array}$} & \multirow[t]{2}{*}{ Impact assessment } \\
\hline & $\begin{array}{l}\text { Expert Panel } \\
\text { Assessment Method } \\
\text { (EPAM) [Australia] }\end{array}$ & & \\
\hline \multirow{5}{*}{$\begin{array}{l}\text { Hydraulic-habitat } \\
\text { modeling }\end{array}$} & Instream Flow & \multirow{5}{*}{$\begin{array}{l}\text { Multiple or single } \\
\text { sites }\end{array}$} & Impact assessment \\
\hline & $\begin{array}{l}\text { (IFIM)/ Physical Habitat } \\
\text { Simulation (PHABSIM) } \\
\text { [USA and others] }\end{array}$ & & \multirow[t]{4}{*}{$\begin{array}{l}\text { River restoration } \\
\text { (including flow } \\
\text { regime) }\end{array}$} \\
\hline & $\begin{array}{l}\text { Computer Aided } \\
\text { Simulation model for } \\
\text { Instream flow } \\
\text { Requirements } \\
\text { (CASIMIR) [Germany] }\end{array}$ & & \\
\hline & $\begin{array}{l}\text { River Simulation } \\
\text { System (RSS) [Norway] }\end{array}$ & & \\
\hline & $\begin{array}{l}\text { Numerical habitat } \\
\text { modeling (NHM) } \\
\text { [Canada] }\end{array}$ & & \\
\hline
\end{tabular}

